\title{
Bioutilization of Chicken Feather Wastes by Newly Isolated Keratinolytic Bacteria Into Protein Hydrolysates With Improved Functionalities
}

\section{Saugat Prajapati}

Asian Institute of Technology

\section{Sushil Koirala}

Asian Institute of Technology

Anil Kumar Anal ( $\square$ anilkumar@ait.ac.th )

Asian Institute of Technology https://orcid.org/0000-0002-8201-112X

\section{Original Article}

Keywords: protein hydrolysates, chicken farm bed, bacteria, feathers.

Posted Date: February 11th, 2021

DOI: https://doi.org/10.21203/rs.3.rs-165809/v1

License: (1) This work is licensed under a Creative Commons Attribution 4.0 International License.

Read Full License

Version of Record: A version of this preprint was published at Applied Biochemistry and Biotechnology on March 29th, 2021. See the published version at https://doi.org/10.1007/s12010-021-03554-4. 


\section{Highlights}

1. Keratinolytic bacterial isolate (KB1) was screened from a chicken farm bed.

2. KB1 was able to degrade chicken feather waste into protein hydrolysates.

3. Protein hydrolysates demonstrated good functional and bioactive properties.

4. Feather Protein hydrolysates from poultry waste can be used in feed applications. 


\section{Graphical Abstract}

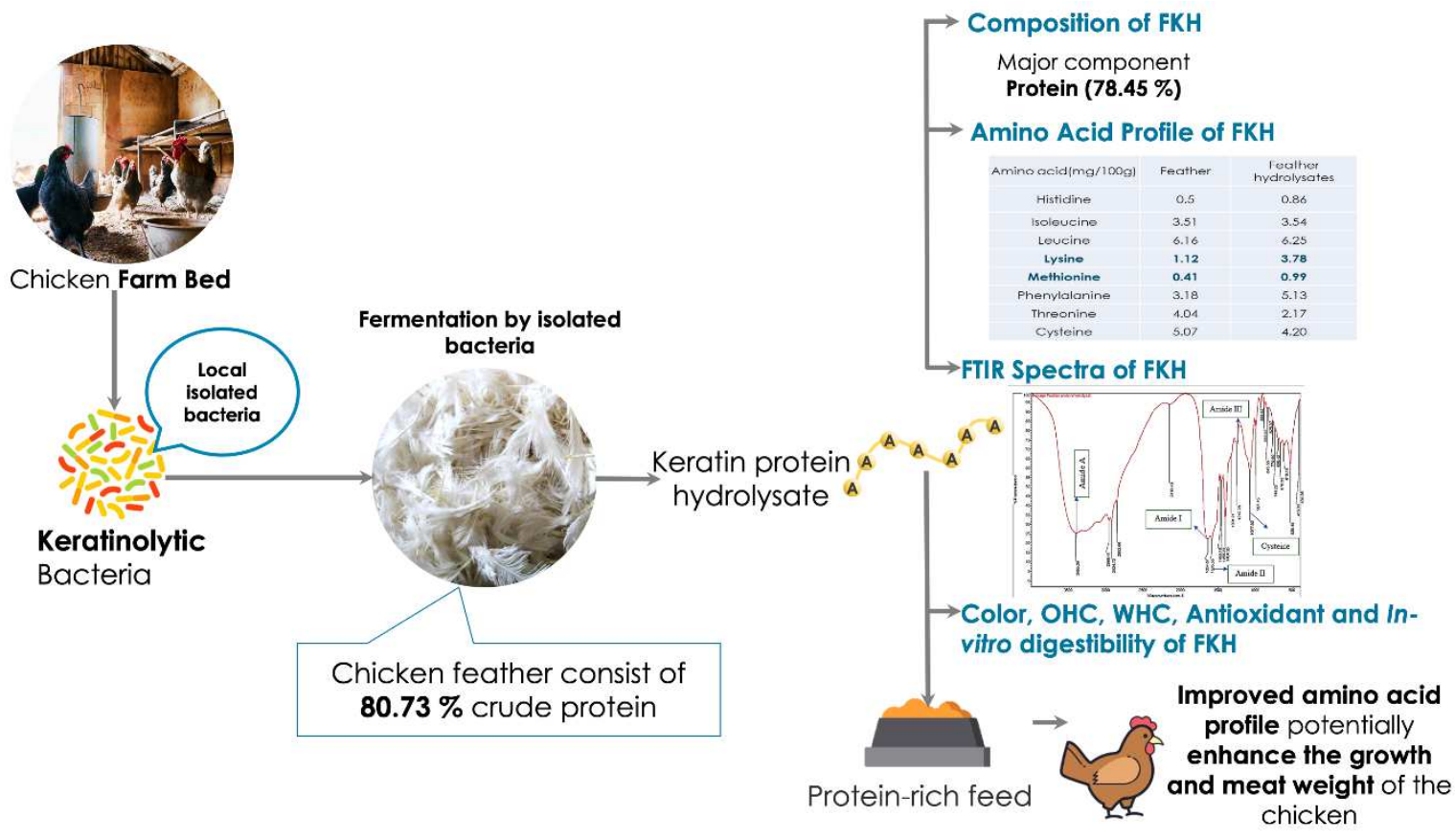


1 Bioutilization of chicken feather wastes by newly isolated keratinolytic

2 bacteria into protein hydrolysates with improved functionalities

3

4 Saugat Prajapati, Sushil Koirala, and Anil Kumar Anal*

5

6 Department of Food, Agriculture, and Bioresources, Asian Institute of Technology, P.O. Box

7 4, Klong Luang, Pathum Thani, 12120. Thailand. Tel: + 66 25246110, Fax: +66-2-5246200

8 ORCID: 0000-0002-8201-112X. Email: anilkumar@ait.ac.th

9

10

$11 *$ Corresponding author

12 Words: 7384 (Including references, figures and tables). 


\section{Abstract}

14 In this study, a novel feather-degrading bacteria B. amyloliquefaciens KB1 was isolated from

15 chicken farm bed (CFB), identified by morphological, physico-biochemical tests followed by

16 16s rDNA analysis. Among observed isolates, bacterial isolate (KB1) showed the highest

17 degree of feather degradation $(74.78 \pm 2.94 \%)$ and total soluble protein $(205 \pm 0.03 \mathrm{mg} / \mathrm{g})$.

18 Using the same species of bacteria, the optimum fermentation condition was found at $40{ }^{\circ} \mathrm{C}$,

$19 \mathrm{pH} \mathrm{9}$, and $1 \%(\mathrm{w} / \mathrm{v})$ feather concentration that produced $260 \mathrm{mg} / \mathrm{g}$ of soluble protein and

$2086.16 \%$ feather degradation using response surface methodology in a Box-Behnken design

21 space. The obtained hydrolysates exhibited bioactive properties. The amino acid profile

22 showed the increase in concentration of essential amino acid compared with feather meal

23 broth. The selection of safe screening source of this new bacteria in CFB produced

24 hydrolysates with enhanced bioactivity applicable for food, feed, and cosmetic applications

25 along with environmental remediation.

26 Keywords: protein hydrolysates, chicken farm bed, bacteria, feathers. 
Intense growth and development of food processing industries have led to a huge amount of waste as a by-product that is mostly discharged into the environment. Chicken feather remains one of the significant by-products from the poultry industry, mainly due to keratin protein that is hard to degrade [1]. In general, each bird has up to $125 \mathrm{~g}$ of feathers and taking into account the daily processing of chicken at 400 million/ day worldwide; this waste reaches five million tons of dry feathers per day [2]. However, chicken feathers are excellent reservoirs of biomolecules with more than $82 \%$ crude protein, out of which $91 \%$ is keratin, predominantly $\beta$-keratin [3]. The higher amount of protein in keratinous waste presents great potential as a source of protein and amino acids for feed, food, and cosmetic applications.

37 Keratin is generally characterized by its ability to resist common proteolytic enzymes and mechanical stability to chemical, hydrothermal and thermo-chemical treatments under high steam. Currently, the industrial process for feather meal involves high temperature and thus the process is costly and energy-intensive. It also results in denaturation and significant loss of essential amino acids producing low-quality protein products [4]. Alkali pretreatments using $\mathrm{KOH}, \mathrm{NaOH}, \mathrm{Ca}(\mathrm{OH})_{2}$ increase the extraction and yield but possess threats in dealing with toxic effluents [5]. Land dumping and incineration are other methods that are likely to result in environmental vandalism. The generation of toxic air emissions from burning feathers is higher than that generated from coal combustion plants [2].

Biotechnological methods have been employed recently to biologically degrade feather

47 keratins as it is considered cost-effective and environment-friendly [6-8]. Various microorganisms producing keratinase enzyme have been known to degrade chicken feathers, mainly keratin, including fungi [9], actinomycetes [10], and Bacillus species [4, 11]. 
51 protein into peptides and amino acids. The screened microorganism can produce keratin

52 hydrolysate; this process benefits in having superior control over the hydrolysis process for

53 the yield. Protein hydrolysates produced from feathers keratin will be cheaper and useful raw

54 materials for animal feed, compostable films, nitrogen-rich fertilizers, reinforced fabrics, and

55 biodegradable materials. Other commercial applications of protein hydrolysates include an

56 effective component of detergents, personal care products, medical treatments of psoriasis

57 and acne, nail treatments, and prion proteins degradation $[12,13]$.

58 Studies have recently been carried out to isolate and identify keratinolytic bacteria from

59 chicken feather dumpsite [14, 15], forest soil [15] and chicken slaughter shops [16]. In all

60 these studies, the authors had reported successful identification of such bacteria with a very

61 high (80-90\%) feather degrading potential within a week of cultivation. To date, there are no

62 reported studies on the screening of keratinolytic bacteria from chicken farm bed. Chicken

63 farm bed (CFB) was chosen as a potential source for isolating the most desirable keratinolytic

64 bacterial species. Furthermore, the natural selection of poultry habitat as CFB as a potential

65 source of keratinolytic bacteria will eliminate the chances of isolating pathogenic bacteria to

66 chicken and humans. In the present study, bioutilization of feather waste was carried out

67 initially by using newly isolated keratinolytic bacteria from CFB. Then, the same isolated

68 bacteria was used in the culture conditions and optimized for protein hydrolysate production

69 in order to enhance the efficiency of feather degradation. 


\section{Materials and methods}

\subsection{Bed and feather samples}

Chicken farm bed $(\mathbf{C F B})$ soil sample and chicken feathers $(\mathbf{C F})$ were supplied by Charoen Pokphand Foods Ltd (CPF) (Chonburi, Thailand). CF was washed two-fold with tap water and finally with distilled water to remove extraneous matters. Similarly, lipid content was removed by immersing the feathers into the solution (chloroform: methanol, 1:1). The washed feathers were dried at $50{ }^{\circ} \mathrm{C}$ for 2 days and stored at room temperature prior to microbial treatment [17]. All other chemicals and used reagents during the study were of analytical grade.

\subsection{Analytical methods}

Moisture content was determined by oven-drying (SLW115TOP, Gibthai, Thailand) at 105 ${ }^{\circ} \mathrm{C}$ to a constant mass (AOAC official method no. 934.01). Fat content was determined using the Soxhlet extraction method (Model 64826, Merck, Germany) with hexane to the solvent's boiling point at $8 \mathrm{~h}$ (AOAC, official method no. 920.39). Crude protein content was determined according to the Kjeldahl method (K1100F, Hanon, China) (AOAC official method no. 981.10) following the AOAC standard methods [18].

\subsection{Isolation of keratinolytic bacteria from chicken farm bed sample}

Initially, the spread plate technique was used to obtain the proteolytic bacteria from CFB. CFB (1 g) was serially diluted up to $10^{-8}$ in a normal saline $(0.8 \mathrm{mg} / 100 \mathrm{~mL})$. Diluted samples $(100 \mu \mathrm{L})$ from each dilution were spread on the skim milk agar plates $(\mathrm{pH} 7)$ and incubated at $37^{\circ} \mathrm{C}$ for $24 \mathrm{~h}$. Bacteria with the visible zone of hydrolysis from $10^{-8}$ dilution were selected and further streaked to obtain the pure colonies. Feather meal broth ( $\mathrm{pH} 7)$ was used to study the keratinolytic activities of isolated colonies according to Daroit et al. (19) by allowing the growth of bacteria for $18 \mathrm{~h}$ that would be used as an inoculum for feather 
94 fermentation. Then, inoculation $\left(1 \%(\mathrm{v} / \mathrm{v}), 10^{7} \mathrm{cfu} / \mathrm{ml}\right)$ was performed in test tubes containing sterile fermentation media $(10 \mathrm{~mL})$ and incubated for 7 days at $37^{\circ} \mathrm{C}$. On the seventh day, the tubes were visually observed for the degradation of feathers. Further, tubes with observed feather degradation were chosen to check their degree of feather degradation (DFD) in 250 mL Erlenmeyer flask with minimal growth medium MGM broth $(100 \mathrm{~mL})(1 \% \mathrm{NaCl} ; 0.05 \%$; $\left.0.07 \% \mathrm{~K}_{2} \mathrm{HPO}_{4} ; 0.14 \% \mathrm{MgSO}_{4} .7 \mathrm{H}_{2} 0\right)$ containing processed sterilized feather $(1 \mathrm{~g})$ at $37^{\circ} \mathrm{C}$ incubation temperature. Then, the supernatant was obtained by centrifugation (Centrikon T324 , Germany) at $6000 \times g$ for $20 \mathrm{~min}$. Morphological characterization and biochemical tests (shape, size, gram staining, spore, methyl red, citrate utilization, casein hydrolysis, gelatin hydrolysis, and motility) were carried out to identify the genus of the isolate.

Then, the isolate's growth pattern was studied in nutrient broth for $72 \mathrm{~h}$ in a shaking flask $\left(150 \mathrm{rpm}\right.$ at $\left.40^{\circ} \mathrm{C}\right)$. The inoculum was prepared by sub-culturing the bacteria for $24 \mathrm{~h}$. It was then diluted to get the inoculum size of $10^{7} \mathrm{CFU} / \mathrm{mL}$. The inoculum $(10 \% \mathrm{v} / \mathrm{v})$ was added to sterilized nutrient broth $(500 \mathrm{~mL})$ for the study, where turbidity method was used for the measurement of optical density (OD) at $600 \mathrm{~nm}$ using UV-Vis Spectrophotometer (Shimadzu UV-1800, Bara-Scientific Co. Ltd., Thailand) at different time intervals (0-70 h).

\subsection{Identification of the feather degrading bacteria}

\subsubsection{Morphological and biochemical tests}

Various morphological (form, culture characteristics) and biochemical tests (methyl red test, citrate utilization test, casein hydrolysis, gelatin hydrolysis, and motility) were carried out according to the standard protocols developed in the biotech lab at AIT for the identification of genus of the feather degrading bacteria. 
117 The identification of the Genomic DNA of feather degrading bacteria was based on 5' $16 \mathrm{~S}$

118 rDNA gene sequence comparison. This DNA was amplified with universal 16S rDNA

119 primers under following PCR (T100 ${ }^{\mathrm{TM}}$ Thermal Cycler, Bio-Rad Laboratories, Inc.,

120 Thailand) conditions: 25 cycles of denaturation at $94{ }^{\circ} \mathrm{C}$ for $1 \mathrm{~min}$, annealing at $50{ }^{\circ} \mathrm{C}$ for 1

$121 \mathrm{~min}$ and elongation at $72{ }^{\circ} \mathrm{C}$ for $3 \mathrm{~min}$. PCR product was amplified using forward primer;

122 20F (5'-GAG TTT GAT CCT GGC TCA G-3') and reverse primer; 1500R (5'-GTT ACC

123 TTG TTA CGA CTT-3'). The nucleotide sequences obtained from all primers were

124 assembled using the BioEdit program (http://www.mbio.ncsu.edu/BioEdit/bioedit.html),

125 followed by deposition of this sequence into the NCBI GenBank

126 (https://www.ncbi.nlm.nih.gov/). The identification of closest phylogenetic neighbors was

127 performed using the BLASTN program against the $16 \mathrm{~S}$ rDNA sequence from previous

128 prokaryotes' database collection. The pairwise sequence similarity with the highest value was

129 calculated using the Global alignment algorithm.

\subsection{Production of feather protein hydrolysate}

131 Keratinolytic bacteria with the highest feather degradation was used as an inoculum for

132 fermenting the raw chicken feather. The bacteria was cultured in nutrient broth for $24 \mathrm{~h}$ at

$13337^{\circ} \mathrm{C}$. Then, an inoculum $1 \%(\mathrm{v} / \mathrm{v})$ containing $10^{7} \mathrm{CFU} / \mathrm{ml}$ was added to a $250 \mathrm{~mL}$ flask containing whole feather $(1 \mathrm{~g})$ and MGM $(100 \mathrm{~mL})$ as a basal medium for 7 days with shaking incubator at $150 \mathrm{rpm}$ (M2019, Velp Scientifica, Europe). After, every 24 h, sample

136 (5 mL) was harvested, filtered (Whatman filter paper No. 1, GE Healthcare UK), and

137 centrifuged (Centrikon T-324, Germany) $(6000 \times g$ for $15 \mathrm{~min})$. The supernatant was used to detect the total soluble protein (TSP) and $\mathrm{pH}$. The degree of feather degradation (DFD) was determined from the residual feather on the seventh day. The broth was passed through 
140 filter paper (Whatman filter paper No. 1, GE Healthcare UK), followed by washing to

141 remove the cell debris and finally dried in a hot-air oven (SLW115TOP, Gibthai, Thailand) at $14260^{\circ} \mathrm{C}$ for $24 \mathrm{~h}$.

143 Then the percentage of feather degradation was calculated using equation 1.

$144 D F D \%=\frac{\text { initial feather weight-residual feather weight }}{\text { initial feather weight }} \times 100$

\subsubsection{Box-Behnken design}

147 For the optimum fermentation conditions, interactive independent effects of feather

148 concentration $\left(1 \%, 3 \%\right.$ and $5 \%$ w/v) $(\mathrm{X} 1)$, initial $\mathrm{pH}(6,7.5$, and 9$)\left(\mathrm{X}_{2}\right)$ and fermentation

149 temperature $\left(30,40\right.$, and $\left.50{ }^{\circ} \mathrm{C}\right)(\mathrm{X} 3)$ as independent variables for the fermentation of chicken 150 feather were varied using Box-Behnken design and response surface methodology (RSM) as a statistical tool according to the Bernal et al. (20) with some modifications. Total Soluble protein (TSP) and degree of feather degradation (DFD) were measured as the response variables. The complete experimental design provided by design expert software (trial

154 version 7.0) contained 15 runs with three replicates at the center point. The data were analyzed using a quadratic polynomial regression model, as shown in equation 2 .

$Y=\beta+\Sigma \beta_{i} X_{i}+\Sigma \beta_{i i} X_{i i} 2+\Sigma \beta_{i j} X_{i} X_{j}$

157 where $Y$ represents protein concentration as a response variable, $\beta$ is a constant identity; independent variables are denoted as $X_{i}$ and $X_{j}$, respectively, and so on.

\subsubsection{Determination of total soluble protein and $\mathrm{pH}$ content}

160 Feather protein hydrolysates were assayed for total soluble protein using Bradford assay

161 (1976) at $595 \mathrm{~nm}$ using a UV-Vis spectrophotometer (UNICAM, Alva, UK) [21]. Bovine serum albumin (BSA) (Sigma Aldrich, USA) was used as a standard to calculate the protein 
content in the sample, expressed in $\mathrm{mg} / \mathrm{mL}$. Finally, the protein content of broth was converted in mg soluble protein per gram of feather. During fermentation, the change in the $\mathrm{pH}$ of the fermentation media was determined by using a portable digital $\mathrm{pH}$ meter (Model 3510, Jenway, UK), calibrated to $\mathrm{pH} 7$ using buffer by directly dipping the electrode in the sample until a constant reading is displayed.

\subsubsection{Partial purification of feather protein hydrolysates}

Ammonium sulfate $(70 \% \mathrm{w} / \mathrm{v})$ precipitation was used to partially purify protein hydrolysates, according to Jain and Anal (22). The clear supernatant was taken in a glass beaker and stored at $4{ }^{\circ} \mathrm{C}$. Salt solution $(700 \mathrm{~g} / \mathrm{L})$ was added dropwise with constant stirring $(600 \mathrm{rpm})$ while maintaining $4{ }^{\circ} \mathrm{C}$ throughout the purification process. The keratin protein was precipitated, and the solution was centrifuged (Centrikon T-324, Germany) at 12,000 $\times g$ for $15 \min (4$ $\left.{ }^{\circ} \mathrm{C}\right)$. The solid pellet contained the precipitated partially purified protein. The protein concentration was dried using a freeze dryer into powder at $-55^{\circ} \mathrm{C}$ until further use.

\subsection{Feather keratin hydrolysate characterization}

\subsubsection{Proximate composition}

Crude protein, fat, and moisture content of feather keratin hydrolysate was performed as earlier described according to AOAC standards [18].

\subsubsection{In vitro protein digestibility}

In vitro protein digestibility of feather protein hydrolysates were carried out according to Fakhfakh et al. (23). Two enzymes; Pepsin (EC 3.4.23.1, from the porcine stomach, Sigma Aldrich, 3000 IU/g), and Pancreatin (EC 232-468-9, from porcine pancreas, Sigma Aldrich, $1400 \mathrm{IU} / \mathrm{g}$ ) were used for the digestibility studies. Freeze-dried protein hydrolysate (1 g) resuspended in Milli-Q water $(1: 1)(1 \mathrm{~mL})$ and feather $(1 \mathrm{~g})$ were taken in a glass beaker, and 
it was dissolved with $2 \mathrm{mg} / \mathrm{mL}$ of pepsin prepared with $2 \mathrm{M} \mathrm{HCl}$ and incubated for $2 \mathrm{~h}$ at

$18737^{\circ} \mathrm{C}$. By the end of the incubation period, the $\mathrm{pH}$ was changed to 8 with $2 \mathrm{M} \mathrm{NaHCO}_{3}$.

188 Then, pancreatin $(2 \mathrm{mg} / \mathrm{mL})$ prepared with $2 \mathrm{M} \mathrm{HCl}$ was added, and incubation was carried

189 for further $16 \mathrm{~h}$. After completion of digestion, the mixtures were centrifuged (Centrikon T-

190324 , Germany). The solubilized protein content in the supernatant was determined by the

191 Kjeldahl method, and \% protein digestion was calculated.

192

$\%$ protein digestion $=\frac{\text { protein content in supernatant by digestion of } 1 \mathrm{~g} \text { sample }}{\text { protein content in } 1 \mathrm{~g} \text { of sample before digestion }}$

193

2.4.3 Color

194 The color spectra of dried protein hydrolysates were determined by using the Hunter-Lab

195 spectrophotometer colorimeter (Color Flex: 45/0, USA). The sample (10 g) was loaded in the 196 sample holder in a light source and covered with a black lid. Mean values from 10

197 observations of $L^{*}, a^{*}$, and $b^{*}$ were used to calculate the whiteness index of keratin

198 hydrolysate, according to Raungrusmee et al. (24) using equation 3.

199 Whiteness index $=100-\left(\left(100-1^{2}\right)+\left(a^{2}\right)+\left(b^{2}\right)\right)^{1 / 2}$

2.4.4 Oil holding capacity $(\mathrm{OHC})$

201 The oil holding capacity of the protein hydrolysates was determined according to Jain and

202 Anal (22). Keratin hydrolysate (100 mg) was dissolved in soybean oil (10 mL) and vortexed

203 for $1 \mathrm{~min}$. They were then centrifuged (Centrikon T-324, Germany) at $2500 \times g$ for 30 min.

204 Free oil was removed, and the adsorbed oil weighed. OHC was calculated as the weight of oil

205 adsorbed per gram of sample.

\subsubsection{Water holding capacity (WHC)}

207 The water holding capacity of the protein hydrolysates was determined according to

208 Raungrusmee and Anal (25). A centrifugal tube (15 mL) was taken and weighed. Keratin 
hydrolysate (400 mg) was loaded in the centrifugal tube in which distilled water $(10 \mathrm{~mL})$ was added, stirred (5 min), and then centrifuged (Centrikon T-324, Germany) at $5000 \times g$ for 30 min. The unabsorbed water was removed by decantation after centrifugation, and the final weight of the tube was recorded. Finally, the amount of water absorbed (g) was calculated per gram of protein hydrolysates.

\subsubsection{Chemical fingerprinting by FTIR spectra}

Using FTIR spectrophotometer (Bruker Vertex 70, Billerica, MA, USA), the structural and functional groups present on the keratin hydrolysate were evaluated, and all spectra were collectively attenuated in the frequency range of 4000-400 $\mathrm{cm}^{-1}$ using 16 scans and $2 \mathrm{~cm}^{-1}$ resolution [26]. The lyophilized sample ( $2 \mathrm{mg}$ ) was pressed into the carver hydraulic press after mixing with $\mathrm{KBr}(100 \mathrm{mg})$. The spectra were analyzed for the structural characteristics of the protein hydrolysates.

\subsubsection{Amino acid profile}

The amino acid composition of the feather protein hydrolysates was analyzed according to Dhakal et al. (27). The protein hydrolysates (50 mg) was treated with $\mathrm{HCL}(6 \mathrm{~N})$ at $110{ }^{\circ} \mathrm{C}$ for $24 \mathrm{~h}$. To remove the residual $\mathrm{HCl}$, the sample was evaporated in a rotary evaporator (Büchi rotavapor R-144, Switzerland). The evaporated sample was dissolved in $10 \mathrm{ml}$ of $0.2 \mathrm{M}$ sodium citrate buffer ( $\mathrm{pH} 2.2)$. The sample was filtered through a $0.45 \mathrm{~mm}$ membrane filter (Titan, Switzerland) and injected into an amino acid analyzer (Biochrome 30, Cambridge, UK) using ninhydrin as a color reactant and on a single ion-exchange resin column. The amino acid composition was converted into $\mathrm{mg}$ amino acid per $100 \mathrm{~g}$ of protein in feather protein hydrolysates and compared with the raw chicken feather meal based on previous studies. 
235 Feather protein hydrolysates were assessed to analyze its ability to reduce the DPPH radical

236 (2,2-diphenyl-1-picrylhydrazyl) (D9132, Sigma-Aldrich, USA) by measuring its absorbance

237 decrease at $517 \mathrm{~nm}$. DPPH solution was made by using DPPH powder $(0.004 \mathrm{~g}$ in $100 \mathrm{~mL}$

$23895 \%$ ethanol), according to Garrido et al. (28). Then stock sample solution of $3 \mathrm{mg} / \mathrm{mL}$ was

239 prepared and diluted to different concentrations $(0.125,0.250,0.50,1$ and $2 \mathrm{mg} / \mathrm{mL})$ with

240 distilled water. DPPH solution was then mixed with a sample solution (1:1) in an opaque

241 glass test tube. A blank solution was prepared with DPPH solution (1 mL) and distilled water

242 (1 mL). The samples were incubated $(30 \mathrm{~min})$ in the dark, and the absorbance was read at 517

$243 \mathrm{~nm}$. The DPPH inhibition activity was determined by using equation (4).

244 DPPH radical scavenging activity $(\%)=\frac{A_{b}-A_{s}}{A_{b}} \times 100$

245 Where, $A b$ and $A s$ are the absorbance of blank and keratin, respectively. The $\mathrm{IC}_{50}$ value,

246 which is the half-maximal concentration of feather keratin hydrolysate to inhibit a substance,

247 was determined using the Graph Pad Prism 7.

\section{$248 \quad 2.5$ Statistical analysis}

249 All the experimental tests were carried out in triplicates. The results were expressed as the 250 mean of the replicas with the standard deviation. Similarly, IBM SPSS statistics 21 was used to analyze the Analysis of Variance (ANOVA). Tukey's method was used as a post-hoc to analyze the significant difference among the samples at 95\% confidence level. 


\section{Results and discussion}

254

255

256

257

258

259

260

261

262

263

264

265

266

267

268

269

270

271

272

273

274

275

\subsection{Isolation of keratinolytic bacteria from chicken farm bed (CFB)}

CFB was selected as the source for the isolation of keratinolytic bacteria. The bed soil sample $(1 \mathrm{~g})$ was serially diluted to $10^{-8}$. The highest dilution showed $3 \times 10^{10} \mathrm{CFU} / \mathrm{mL}$ bacterial population after spreading $(100 \mu \mathrm{L})$ sample on the skim milk agar (SMA) (incubated at $37{ }^{\circ} \mathrm{C}$ for $24 \mathrm{~h}$ ). Each distinct colony was streaked on the SMA plates to get pure culture. A single colony from each of the thirty plates were then tested to observe their ability to degrade the feather in a test tube containing $10 \mathrm{~mL}$ of MGM broth and a single feather piece as a sole source of carbon and nitrogen. The initial $\mathrm{pH}$ was maintained 7.5 and incubated for 7 days at $37^{\circ} \mathrm{C}$. Out of thirty test isolates, only eight were found to show the feather degradability after 7 days of hydrolysis, and thus the isolate was named KB1, KB2, KB3, KB4, KB5, KB6, $\mathrm{KB} 7$, and $\mathrm{KB} 8$.

\subsubsection{Measurement of the degree of feather degradation and total soluble proteins of isolates}

The isolates were grown in an Erlenmeyer flask $(250 \mathrm{~mL})$ with MGM broth $(100 \mathrm{~mL})$ and chicken feathers $(1 \mathrm{~g})$. Table 1 illustrates the degree of feather degradation and total soluble proteins released by these bacterial isolates during feather degradation. The maximum $(74.78$ $\pm 2.94 \%)$ and minimum $(11.1 \pm 1.23 \%)$ degradation of the whole feather in the broth were shown by the isolates $\mathrm{KB} 1$ and $\mathrm{KB} 2$, respectively. The same isolates produced maximum soluble protein KB1 $(205 \pm 0.03 \mathrm{mg} / \mathrm{g}$ of the dry feather $)$ and $\mathrm{KB} 2(39 \pm 0.06 \mathrm{mg} / \mathrm{g}$ dry feather). Based on these findings, keratinolytic bacterial isolate (KB1) was chosen as appropriate. Fig. 1 illustrates the degradation of a feather (a) control (in a feather meal) (b) solubilized due to isolated bacteria KB1. 
277 Fig 1. here

278 3.1.2 Morphological characterization and biochemical test of the isolate

279 Morphological studies and biochemical tests for isolate KB1 showed that the isolate was 280 gram-positive, endospore-forming, and a motile bacillus. Similarly, the culture study in

281 nutrient agar showed that the colonies were creamy white in color, mucoid, raised,

282 translucent, and exhibits the entire margin. The isolate showed negative results to the methyl

283 red test, citrate utilization test, and positive results to casein and gelatin hydrolysis.

\subsubsection{Optimal growth conditions}

285 The growth of the bacterial isolate KB1 was studied in nutrient broth for $72 \mathrm{~h}$, which showed 286 the initial lag phase of $2 \mathrm{~h}$ and onset of log-phase till $42 \mathrm{~h}$ of growth (Supplementary file

287 figure S1). Then, the optical density started to fall, exhibiting the decline phase. The optical 288 density (OD) measured as absorbance at $600 \mathrm{~nm}$ drops gradually with no visible stationary

289 phase. This is because the identified isolate was endospore former, which means due to the 290 depletion of nutrient and accumulation of toxic substances, vegetative cells of endospore former start to undergo spore formations which are smaller in size than vegetative cells [29].

\subsubsection{Identification of the bacteria by $16 \mathrm{~s}$ rDNA}

293

294
The bacterial isolate KB1 was identified using single-strand 16s rDNA sequencing for species characterization phylogenetically. BLAST search engine showed that the species had the highest similarity with the Bacillus siamensis and Bacillus velezensis $99.78 \%$. The phylogenetic analysis of the bacteria that was observed to be located in the same cluster with Bacillus siamensis (Fig. 2). Moreover, it showed 99.63\% similarity with Bacillus amyloliquefaciens and Bacillus subtilis sub. Subtilis. Fan et al. (30) suggested that all the 
closest neighbors of KB1, including B. amyloliquefaciens, B. siamensis, and B. velezensis, do form an "operational group" as B. amyloliquefaciens within the B. subtilis species complex.

301 Therefore, the isolated bacteria KB1 can be related to B. amyloliquefaciens.

302 Fig. 2 here

\subsection{Optimization of fermentation condition using response surface methodology}

304 The identified bacterial isolate KB1 was used for the fermentation of raw chicken feathers in MGM broth. The fermentation process was optimized by using RSM with independent factors; initial feather concentration $(1 \%, 3 \%$, and $5 \% \mathrm{w} / \mathrm{v})$ : Initial $\mathrm{pH}(6,7.5$, and 9): fermentation temperature $\left(30,40\right.$ and $\left.50{ }^{\circ} \mathrm{C}\right)$ against the response variables; total soluble protein $(\mathrm{mg} / \mathrm{g})$ and the degree of feather degradation (\%) using Box-Behnken design.

Table 2 illustrates the results obtained after 15 sets of experiments with experimental and predicted values. Regression analysis was performed for the fitting of the response surface model in the given experimental design space. Following this, a multiple regression quadratic equation was obtained that represents an empirical relationship between the responses and the independent variables as shown:

$Y_{1}=116.82-80.43 X_{1}+9.08 X_{2}-0.69 X_{3}-1.36 X_{1} X_{2}+0.39 X_{1} X_{3}-1.26 X_{2} X_{3}+$

$31545.61 X_{1}^{2}-5.69 X_{2}^{2}+1.21 X_{3}^{2}$

$Y_{2}=74.50-14.84 X_{1}+8.45 X_{2}+0.088 X_{3}-0.028 X_{1} X_{2}+0.91 X_{1} X_{3}-1.12 X_{2} X_{3}-$

$317 \quad 4.53 X_{1}^{2}-10.41 X_{2}^{2}-1.30 X_{3}^{2}$

318 Where $\mathrm{Y}_{1}$ and $\mathrm{Y}_{2}$ are total soluble protein and degree of feather degradation, respectively.

319 Similarly, $\mathrm{X}_{1}, \mathrm{X}_{2}$ and $\mathrm{X}_{3}$ are initial feather concentration $\%(\mathrm{w} / \mathrm{v}), \mathrm{pH}$ and fermentation temperature $\left({ }^{\circ} \mathrm{C}\right)$ respectively.

321 The effects of each independent variable on the response were determined with the help of F-

322 test (ANOVA), where initial feather concentration $(\% \mathrm{w} / \mathrm{v})$ and $\mathrm{pH}$ had a significant effect on 
the production of total soluble protein $(\mathrm{mg} / \mathrm{g})$ and degree of feather degradation $(\%)(p<$ 0.001). Lack of fit test helps to measure the model's failure to represent predicted and observed data in the experimental design space. The model had a non-significant lack of fit value ( $\mathrm{p}$ values) of 0.0789 and 0.4136 , respectively for total soluble protein and degree of feather degradation, meaning the variation of data fits the actual response variable with the model able to predict values of total soluble protein $(\mathrm{mg} / \mathrm{g})$ and degree of feather degradation $(\%)$. The $\mathrm{R}^{2}$ value for soluble protein and the degree of feather degradation was 0.9866 and 0.9781, respectively, which showed a good fit of the empirical model with the experimental data.

\section{Table 2 here}

Fig. 3 (a) and 3 (b) illustrate the response surface (3-D) plots with interactive effects of two independent variables on a single response variable. The soluble proteins were found to be increasing at increasing alkaline condition and decreasing feather condition. Similar findings were observed in the degree of feather degradation. The maximum production of soluble protein $(260 \mathrm{mg} / \mathrm{g})$ was observed at initial $\mathrm{pH} 9$ and $1 \%(\mathrm{w} / \mathrm{v})$ feather concentration, with $86.16 \%$ feather degradation. At higher initial feather concentration, it was observed that soluble protein release and feather degradation was minimum representing $56.20 \mathrm{mg} / \mathrm{g}$ and $34.19 \%$, respectively. At higher substrate concentration, the enzyme excretion is lower and hence is the lower degradation of feather and soluble protein production [31]. However, the influence of temperature was not significant for both the production of soluble protein and feather degradation $(p>0.05)$. The Design Expert Software determined the optimum fermentation conditions based on the desirability function (Design Expert). The optimum condition $($ desirability $=0.976)$ includes initial feather concentration of $1 \%(\mathrm{w} / \mathrm{v}), \mathrm{pH}$ of 9 , and fermentation temperature of $40{ }^{\circ} \mathrm{C}$ at which the maximum protein concentration and degree of feather degradation were reported to be $260 \mathrm{mg} / \mathrm{g}$ and $86.16 \%$ respectively. 


\subsection{Characterization of feather protein hydrolysates}

3.3.1 Physico-chemical composition of raw feathers and Feather protein hydrolysates (FPH)

351 Table 3 illustrates the physico-chemical characterization of FPH compared to raw feathers.

352 Raw feathers consists of $80.73 \pm 1.53 \%$ crude protein as a major constituent. Considering

353 that feathers are composed of more than $80 \%$ crude protein (keratin), the use of this protein

354 source can be of great interest to produce protein hydrolysates [3]. Other components

355 analysed include fat $(1.27 \pm 0.05 \%)$, ash content $(0.83 \pm 0.07 \%)$, volatile compounds (80.84

$356 \pm 0.90 \%)$ and fixed carbon $(5.41 \pm 0.07 \%)$. Whereas FPH constitutes a remarkable amount

357 of protein $(78.45 \pm 0.38 \%)$. The reduction in the protein content is due to utilization by

358 bacterial culture to increase biomass; hence the output protein is slightly less than that of a

359 raw feather. The low moisture content $(3.54 \pm 0.04 \%)$ of the hydrolysate is due to the freeze-

360 drying, which helps extend the product's shelf-life.

Table 3 here

362 In vitro protein digestibility plays a significant role in the formulation of food and feed

363 products. The in vitro protein digestibility of raw feather and feather protein hydrolysates were observed in vitro using pepsin and pancreatin and it was observed as $1.75 \pm 0.5 \%$ and $82.36 \pm 0.62 \%$, respectively. Raw feathers are primarily composed of keratin protein, commonly resistant to enzymes like pepsin, pancreatin, trypsin, papain, etc. [31]. However,

367 newly isolated bacteria KB1 solubilized the native keratin protein into peptides and amino 368 acids, which are easily digested by the gastrointestinal enzymes. Fakhfakh et al. (23) used commercially available B.pumilus A1 to produce feather protein hydrolysates with an in vitro digestibility of $98 \pm 0.7 \%$. 


\subsubsection{Color of protein hydrolysates}

372 The color parameters of sample hydrolysates were measured with Hunter Colorimeter. The

373 parameters were expressed as $\mathrm{L}^{*}$ for darkness to lightness, $\mathrm{a}^{*}$ for greenness to redness, and

$374 b^{*}$ for blueness to yellowness. $L^{*} a^{*}$ and $b^{*}$ values were found to be $76.49 \pm 0.08,3.19 \pm$

3750.22 , and $23.27 \pm 1.63$, respectively. The whiteness index of produced protein hydrolysates

376 was found to be $66.77 \pm 1.12$.

\subsubsection{Oil holding capacity $(\mathrm{OHC})$ and water holding capacity (WHC) feather protein}

378 hydrolysates

379 Feather protein hydrolysate exhibited excellent OHC (5.46 g/g) and WHC (3.35 g/ g) of

380 protein hydrolysate, respectively. The increased concentration of polar groups such as $\mathrm{COOH}$

381 and $\mathrm{NH}_{2}$ that is caused by enzymatic hydrolysis has a substantial effect on the amount of

382 adsorbed oil and water [22]. Oil and water-holding properties of protein hydrolysates are

383 crucial in food and feed formulation. These properties directly affect the texture, color,

384 appearance, and the shelf-life of the final product. The higher the water holding capacity, the

385 more the energy to reduce the moisture content and even reduce shelf life. However, it can

386 help to solubilize the water-soluble component in the food matrix (Jain \& Anal, 2017).

387 Similarly, higher the oil holding capacity, the product's palatability will be increased with a

388 soft texture and higher fat-soluble nutrients. However, the products will have a lesser shelf-

389 life as the product may face rancidity. The water-holding capacity is due to the hydrophilic

390 moiety of proteins. The oil holding capacity results from a lipophilic and non-polar moiety of 391 protein [32].

\subsubsection{Fourier- transform infrared spectroscopy (FTIR) of feather protein hydrolysates}

393 The FTIR spectra of feather protein hydrolysates exhibiting different peaks of wave numbers

394 representing the presence of Amide A, I, II, and III bands is shown in Fig. 4. The hydrolysate 
exhibited a peak at $3404.39 \mathrm{~cm}^{-1}$, which showed the presence of amide A with a wave

number close to $3500-3200 \mathrm{~cm}^{-1}$. N-H stretching vibration is associated with the absorption

397 characteristic of amide A [33]. Amide I exhibit the wavenumber of $1700-1600 \mathrm{~cm}^{-1}$, which is due to the stretching vibration of $\mathrm{C}=\mathrm{O}$ bonds, whereas Amide II exhibits the wave number $1580-1480 \mathrm{~cm}^{-1}$. The occurrence of amide II is derived from $\mathrm{N}-\mathrm{H}$ and $\mathrm{C}-\mathrm{H}$ stretching vibrations. Amide I possess the strongest transmission band and is very sensitive to secondary based on different hydrogen-bonding environments for $\alpha$-helix, $\beta$-sheet, turn, and unordered conformation [34]. The protein hydrolysate exhibited the wavenumbers of $1634.87 \mathrm{~cm}^{-1}$ and $1585.55 \mathrm{~cm}^{-1}$, therefore, confirmed the presence of Amide I and amide II. Also, the presence of a band at 1634.87 reflects that the protein is comprised up of strong 405 beta sheets. The absorption peak of protein hydrolysates at $1300-1200 \mathrm{~cm}^{-1}$ stands for amide III, which signifies the stretching of C-N and deformation of N-H bonds. The keratin hydrolysate exhibited the wavenumber of $1247.28 \mathrm{~cm}^{-1}$, which showed the presence of amide III. The presence of bands between $1034-1078.28 \mathrm{~cm}^{-1}$ represents the presence of cysteine, 409 formed as the result of disulfide bond broken down during the dissolution of keratin. The 410 feather keratin hydrolysate exhibited band at wave number of $1077.28 \mathrm{~cm}^{-1}$ conforming the same. Similar results were reported by Colembergue et al. (35) with chicken feather protein.

\section{$412 \quad$ Fig. 4 here}

\subsubsection{Amino acid composition}

414 The study of amino acid composition is significant as the biological and functional activities

415 of protein hydrolysates depend on the type and composition of amino acids within the protein 416 sequence. The amino acid composition of feather protein hydrolysates was determined, as

417 shown in table 4. The amino acid -glutamic acid, leucine, proline, valine, and aspartic acid 418 were found to be present in the highest amount. Similarly, the protein hydrolysates showed 
high levels of hydrophobic amino acids (alanine, cystine, isoleucine, leucine, methionine,

420 phenylalanine, proline, tryptophan, tyrosine, and valine) contributing to $55.01 \%$ and good

421 quantities of aromatic amino acids (tryptophan, phenylalanine, and tyrosine) contributing to

$42214.29 \%$ of the total amino acids respectively. These amino acids are known to possess

423 antioxidant activities, which help to justify the high free radical scavenging abilities obtained

424 from the fermented protein hydrolysates. The protein hydrolysates also demonstrated good

425 amounts of essential amino acids (histidine, isoleucine, leucine, lysine, methionine,

426 phenylalanine, threonine, tryptophan, and valine) in various food and cosmetic applications.

427 Zhao et al. (36) evaluated the composition of essential amino acids in chicken feather as

428 histidine $(0.5 \mathrm{mg} / 100 \mathrm{~g}$ protein $)$, isoleucine $(3.51 \mathrm{mg} / 100 \mathrm{~g}$ protein $)$, leucine $(6.16 \mathrm{mg} / 100$

$429 \mathrm{~g}$ protein), lysine $(1.12 \mathrm{mg} / 100 \mathrm{~g}$ protein), methionine $(0.41 \mathrm{mg} / 100 \mathrm{~g}$ protein),

430 phenylalanine $(3.18 \mathrm{mg} / 100 \mathrm{~g}$ protein), Threonine (4.04 mg/ $100 \mathrm{~g}$ protein) and cysteine

431 (5.07 $\mathrm{mg} / 100 \mathrm{~g}$ protein). In our study, as illustrated in table 4, all essential amino acids

432 increased with the most significant increment seen in lysine $(3.78 \mathrm{mg} / 100 \mathrm{~g}$ protein $)$ and

433 Methionine (0.99 (mg/ $100 \mathrm{~g}$ protein). Improved amino acid profile can potentially enhance

434 the growth and meat weight of the chicken applicable to chicken feed industry.

435 Table 4 here

436 3.3.6 In vitro antioxidant properties of feather protein hydrolysates

437 As illustrated in Fig. 5, the antioxidant abilities of feather protein hydrolysates were studied

438 with DPPH radical scavenging activity, which showed that the inhibition activity increases

439 with the hydrolysate concentration. DPPH being a free radical, when protonated, is

440 scavenged, which reduces the absorbance at $517 \mathrm{~nm}$, which is the measure of radical

441 scavenging activity. The IC50 value of the feather keratin hydrolysate was found to be 0.7

$442 \mathrm{mg} / \mathrm{mL}$. The IC50 DPPH radical scavenging activity of this hydrolysate was found to be 
443 lower (meaning higher antioxidant abilities) than the two chemically extracted keratin

444 hydrolysate A and hydrolysate C by Alahyaribeik and Ullah (37) with IC50 of $8.21 \pm 0.231$

$445 \mathrm{mg} / \mathrm{mL}$ and $2.23 \pm 0.316 \mathrm{mg} / \mathrm{mL}$ respectively. Fakhfakh et al. (23) observed an $\mathrm{IC} 50$ value of

$446 \quad 0.3 \mathrm{mg} / \mathrm{mL}$ from the chicken feather hydrolysate using B. pumilus A1 while

447 Chryseobacterium sediminis RCM-SSR-7 isolated and identified from feather dumping sites

448 in India exhibited $0.102 \mathrm{mg} / \mathrm{mL}$ radical scavenging activity in its hydrolysates [38].

449 The free radical scavenging abilities of the feather keratin hydrolysate can be positively

450 correlated with its amino acid composition. As can be observed from the amino acid analysis,

451 the protein hydrolysates showed high levels of hydrophobic amino acids (alanine, cystine,

452 isoleucine, leucine, methionine, phenylalanine, proline, tryptophan, tyrosine, and valine).

453 Cysteine is produced as a product during the breakdown of the disulfide bond present in the

454 feather by microbial keratinase, which acts as a potent antioxidant. Also, Cysteine-SH present

455 in feather peptide is a strong hydrogen donor to free radicals. Furthermore, sulfenic acid (-

$456 \mathrm{SOH}$ ) is produced when the chicken feather is reduced under alkaline conditions. This acid is

457 yet another prime antioxidant in keratin hydrolysate [12]. This confirms the presence of

458 electron-donating hydrolysates and peptides in feather keratin hydrolysate, which could be

459 used as primary antioxidants that are applicable to many food, pharmaceutical, and cosmetic

460 industrial products.

$461 \quad$ Fig. 5 here 


\section{Conclusion}

463 Chicken feather degrading bacteria Bacillus amyloliquefaciens KB1 was isolated and

464 identified from chicken farm bed and the same isolated bacteria with maximum total soluble

465 protein $(250.33 \mathrm{mg} / \mathrm{mL})$ and the highest feather degradation $(86.17 \%)$ obtained after

466 fermentation was utilized successfully to degrade chicken feather. The fermentation process

467 of a chicken feather by isolated bacteria KB1 was optimized using feather concentration,

468 initial $\mathrm{pH}$, and incubation temperature. The feather protein hydrolysates were characterized

469 using FTIR spectroscopy and amino acid analysis. Similarly, these hydrolysates enhanced

470 functional properties like antioxidant abilities and in-vitro digestibility, which can be

471 associated with the breakdown of protein (keratin) during the fermentation process. Thus, the

472 application of green technology-based fermentation by newly isolated and identified bacteria

473 was highly effective in valorizing feather waste in producing feather keratin hydrolysate.

474 Such hydrolysates of chicken feathers from chicken feather waste hold tremendous potential

475 for various feed, pharmaceutical, and cosmetic industries.

\section{$476 \quad$ Funding}

477 The authors did not receive any funding for this research.

478 Conflict of interest

479 There are no conflict of interest among the author (s).

480 Availability of data and material

481 Available (if necessary)

482 Code availability

483 Not applicable 
485 Authors' contributions

486 All authors contributed to the study conception and design. Conceptualization: Saugat

487 Prajapati, Sushil Koirala, Methodology: Saugat Prajapati, Anil Kumar Anal, Formal

488 analysis and investigation: Saugat Prajapati, Anil Kumar Anal, Writing - original draft

489 preparation: Saugat Prajapati, Writing - review and editing: Sushil Koirala, Anil Kumar

490 Anal, Supervision: Anil Kumar Anal. All authors read and approved the final manuscript.

491

492 Ethics approval

493 Not Applicable (NA)

494 Consent to participate

495 Not Applicable (NA)

496 Consent for publication

497 Consent approved 
498

499

500

501

502

503

504

505

506

507

508

509

510

511

512

513

514

515

516

517

518

519

520

521

522

523

524

525

526

527

528

529

530

\section{References}

1. Łaba, W., Żarowska, B., Chorążyk, D., Pudło, A., Piegza, M., Kancelista, A., \& Kopeć, W. (2018) New keratinolytic bacteria in valorization of chicken feather waste. AMB Express, 8, 9.

2. Tesfaye, T., Sithole, B., Ramjugernath, D., \& Chunilall, V. (2017) Valorisation of chicken feathers: Characterisation of chemical properties. Waste Management, 68, 626-635.

3. Lasekan, A., Bakar, F. A., \& Hashim, D. (2013) Potential of chicken by-products as sources of useful biological resources. Waste Management, 33, 552-565.

4. Haddar, H. O., Zaghloul, T. I., \& Saeed, H. M. (2009) Biodegradation of native feather keratin by Bacillus subtilis recombinant strains. Biodegradation, 20, 687.

5. Gupta, R., Rajput, R., Sharma, R., \& Gupta, N. (2013) Biotechnological applications and prospective market of microbial keratinases. Applied Microbiology and Biotechnology, 97, 9931-9940.

6. Brandelli, A., Daroit, D. J., \& Riffel, A. (2010) Biochemical features of microbial keratinases and their production and applications. Applied Microbiology and Biotechnology, 85, 1735-1750.

7. Taskin, M., \& Kurbanoglu, E. (2011) Evaluation of waste chicken feathers as peptone source for bacterial growth. Journal of Applied Microbiology, 111, 826-834.

8. Lange, L., Huang, Y., \& Busk, P. K. (2016) Microbial decomposition of keratin in nature - a new hypothesis of industrial relevance. Applied Microbiology and Biotechnology, 100, 2083-2096.

9. Anbu, P., Gopinath, S. C., Hilda, A., Mathivanan, N., \& Annadurai, G. (2006) Secretion of keratinolytic enzymes and keratinolysis by Scopulariopsis brevicaulis and Trichophyton mentagrophytes: regression analysis. Canadian Journal of Microbiology, 52, 1060-1069.

10. Syed, D. G., Lee, J. C., Li, W.-J., Kim, C.-J., \& Agasar, D. (2009) Production, characterization and application of keratinase from Streptomyces gulbargensis. Bioresource Technology, 100, 1868-1871.

11. Kumar, R., Balaji, S., Uma, T., Mandal, A., \& Sehgal, P. (2010) Optimization of influential parameters for extracellular keratinase production by Bacillus subtilis (MTCC9102) in solid state fermentation using horn meal—a biowaste management. Applied Biochemistry and Biotechnology, 160, 30. 
531 12. Wan, M.-Y., Dong, G., Yang, B.-Q., \& Feng, H. (2016) Identification and

532

533

534

535

536

537

538

539

540

541

542

543

544

545

546

547

548

549

550

551

552

553

554

555

556

557

558

559

560

561

562

563 characterization of a novel antioxidant peptide from feather keratin hydrolysate. Biotechnology Letters, 38, 643-649.

13. Forgács, G., Lundin, M., Taherzadeh, M. J., \& Horváth, I. S. (2013) Pretreatment of chicken feather waste for improved biogas production. Applied Biochemistry and Biotechnology, 169, 2016-2028.

14. Veenayohini, K., \& Sangeetha, D. (2016) Isolation and identification of keratinolytic bacteria from poultry waste and assessment of its keratinase activity on chicken feathers. International Journal of Applied Research, 2, 396-402.

15. Dada, M., \& Wakil, S. (2019) Screening and Characterisation of Keratin-Degrading Bacillus sp. from Feather Waste. Biotechnology Journal International, 1-12.

16. Sahoo, D. K., Das, A., Thatoi, H., Mondal, K. C., \& Mohapatra, P. K. D. (2012) Keratinase production and biodegradation of whole chicken feather keratin by a newly isolated bacterium under submerged fermentation. Applied Biochemistry and Biotechnology, 167, 1040-1051.

17. Cheong, C. W., Lee, Y. S., Ahmad, S. A., Ooi, P. T., \& Phang, L. Y. (2018) Chicken feather valorization by thermal alkaline pretreatment followed by enzymatic hydrolysis for protein-rich hydrolysate production. Waste Management, 79, 658-666.

18. AOAC, G. (2016) Official methods of analysis of AOAC International. Rockville, MD: AOAC International, ISBN: 978-0-935584-87-5.

19. Daroit, D. J., Corrêa, A. P. F., \& Brandelli, A. (2011) Production of keratinolytic proteases through bioconversion of feather meal by the Amazonian bacterium Bacillus sp. P45. International Biodeterioration \& Biodegradation, 65, 45-51.

20. Bernal, C., Diaz, I., \& Coello, N. (2006) Response surface methodology for the optimization of keratinase production in culture medium containing feathers produced by Kocuria rosea. Canadian Journal of Microbiology, 52, 445-450.

21. Kruger, N. J. (2009), in The protein protocols handbook, Springer, pp. 17-24.

22. Jain, S., \& Anal, A. K. (2016) Optimization of extraction of functional protein hydrolysates from chicken egg shell membrane (ESM) by ultrasonic assisted extraction (UAE) and enzymatic hydrolysis. LWT-Food Science and Technology, 69, 295-302.

23. Fakhfakh, N., Ktari, N., Haddar, A., Mnif, I. H., Dahmen, I., \& Nasri, M. (2011) Total solubilisation of the chicken feathers by fermentation with a keratinolytic bacterium, 
Bacillus pumilus A1, and the production of protein hydrolysate with high antioxidative activity. Process Biochemistry, 46, 1731-1737.

24. Raungrusmee, S., Shrestha, S., Sadiq, M. B., \& Anal, A. K. (2020) Influence of resistant starch, xanthan gum, inulin and defatted rice bran on the physicochemical, functional and sensory properties of low glycemic gluten-free noodles. LWT-Food Science and Technology, 109279.

25. Raungrusmee, S., \& Anal, A. K. (2019) Effects of Lintnerization, Autoclaving, and Freeze-Thaw Treatments on Resistant Starch Formation and Functional Properties of Pathumthani 80 Rice Starch. Foods, 8, 558.

26. Vidal, A. R., Duarte, L. P., Schmidt, M. M., Cansian, R. L., Fernandes, I. A., de Oliveira Mello, R., Demiate, I. M., \& Dornelles, R. C. P. (2020) Extraction and characterization of collagen from sheep slaughter by-products. Waste Management, $102,838-846$.

27. Dhakal, D., Koomsap, P., Lamichhane, A., Sadiq, M. B., \& Anal, A. K. (2018) Optimization of collagen extraction from chicken feet by papain hydrolysis and synthesis of chicken feet collagen based biopolymeric fibres. Food Bioscience, 23, 23-30.

28. Garrido, T., Gizdavic-Nikolaidis, M., Leceta, I., Urdanpilleta, M., Guerrero, P., de la Caba, K., \& Kilmartin, P. A. (2019) Optimizing the extraction process of natural antioxidants from chardonnay grape marc using microwave-assisted extraction. Waste Management, 88, 110-117.

29. Sella, S. R., Vandenberghe, L. P., \& Soccol, C. R. (2014) Life cycle and spore resistance of spore-forming Bacillus atrophaeus. Microbiological Research, 169, 931939.

30. Fan, B., Blom, J., Klenk, H.-P., \& Borriss, R. (2017) Bacillus amyloliquefaciens, Bacillus velezensis, and Bacillus siamensis form an "operational group B. amyloliquefaciens" within the B. subtilis species complex. Frontiers in Microbiology, $8,22$.

31. Parrado, J., Rodriguez-Morgado, B., Tejada, M., Hernandez, T., \& Garcia, C. (2014) Proteomic analysis of enzyme production by Bacillus licheniformis using different feather wastes as the sole fermentation media. Enzyme and Microbial Technology, 57, $1-7$.

32. Zou, Y., Wang, L., Cai, P., Li, P., Zhang, M., Sun, Z., Sun, C., Xu, W., \& Wang, D. (2017) Effect of ultrasound assisted extraction on the physicochemical and functional 
598

599

600

601

602

603

604

605

606

607

608

609

610

611

612

613

614

615

616

617

618

619 properties of collagen from soft-shelled turtle calipash. International Journal of Biological Macromolecules, 105, 1602-1610.

33. Zhou, C., Li, Y., Yu, X., Yang, H., Ma, H., Yagoub, A. E. A., Cheng, Y., Hu, J., \& Otu, P. N. Y. (2016) Extraction and characterization of chicken feet soluble collagen. LWT-Food Science and Technology, 74, 145-153.

34. Miller, L. M., Bourassa, M. W., \& Smith, R. J. (2013) FTIR spectroscopic imaging of protein aggregation in living cells. Biochimica et Biophysica Aacta (BBA)Biomembranes, 1828, 2339-2346.

35. Colembergue, J. P., Rios, D. G., \& Prentice, C. (2016) Evaluation and characterization of protein isolates from poultry processing industries by-product. International Journal of Applied Science and Technology, 6, 79-87.

36. Zhao, W., Yang, R., Zhang, Y., \& Wu, L. (2012) Sustainable and practical utilization of feather keratin by an innovative physicochemical pretreatment: high density steam flash-explosion. Green Chemistry, 14, 3352-3360.

37. Alahyaribeik, S., \& Ullah, A. (2020) Methods of keratin extraction from poultry feathers and their effects on antioxidant activity of extracted keratin. International Journal of Biological Macromolecules, 148, 449-456.

38. Kshetri, P., Roy, S. S., Sharma, S. K., Singh, T. S., Ansari, M. A., Prakash, N., \& Ngachan, S. (2019) Transforming chicken feather waste into feather protein hydrolysate using a newly isolated multifaceted keratinolytic bacterium Chryseobacterium sediminis RCM-SSR-7. Waste and Biomass Valorization, 10, 1-11. 
620 Figure captions

621 Fig. 1 Chicken feather degradation by bacterial isolate KB1 (a) control (without bacteria) and

622 (b) solubilized feather by bacterial isolate KB1 in a minimal basal media

623 Fig. 2 Phylogenetic relationship of the $16 \mathrm{~S}$ rDNA sequence of keratinolytic bacteria KB1

624 with $16 \mathrm{~S}$ rDNA of closest Bacillus species

625 Fig. 3 (a) 3-D response surface plot showing the interactive effect of initial $\mathrm{pH}$, initial feather

626 concentration, and temperature on the production of total soluble protein

627 Fig. 3 (b) 3-D response surface plot showing interactive effect of initial pH, initial feather 628 concentration and temperature on the degree of feather degradation

629 Fig. 4 Fourier-transform infrared (FTIR) spectrum of feather protein hydrolysates

630 Fig. 5 In vitro \% inhibition of DPPH antioxidant activity of feather protein hydrolysates 


\section{Figure 1}

632

633

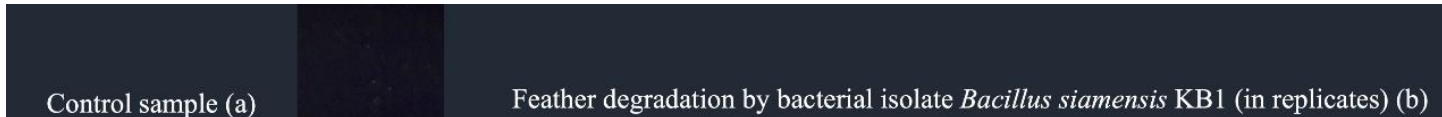

634

635

636

637

638

639

Control sample (a) $\quad$ Feather degradation by bacterial isolate Bacillus siamensis KB1 (in replicates) (b)

640

\section{Figure 2}

642

643

644

645

646

647

648

649

650

651

652

653

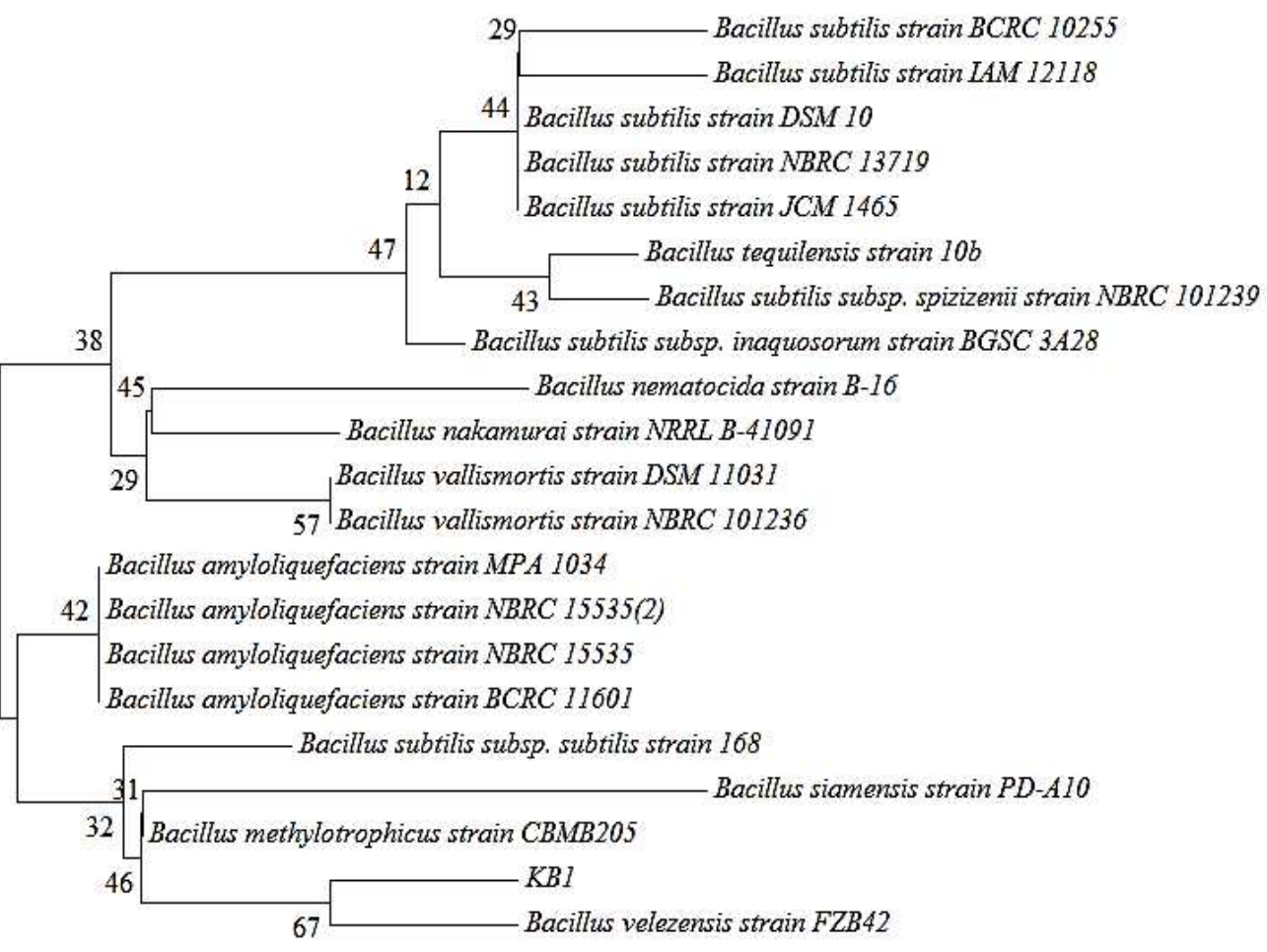


Figure 3 (a)

656

657

658

659

660

661

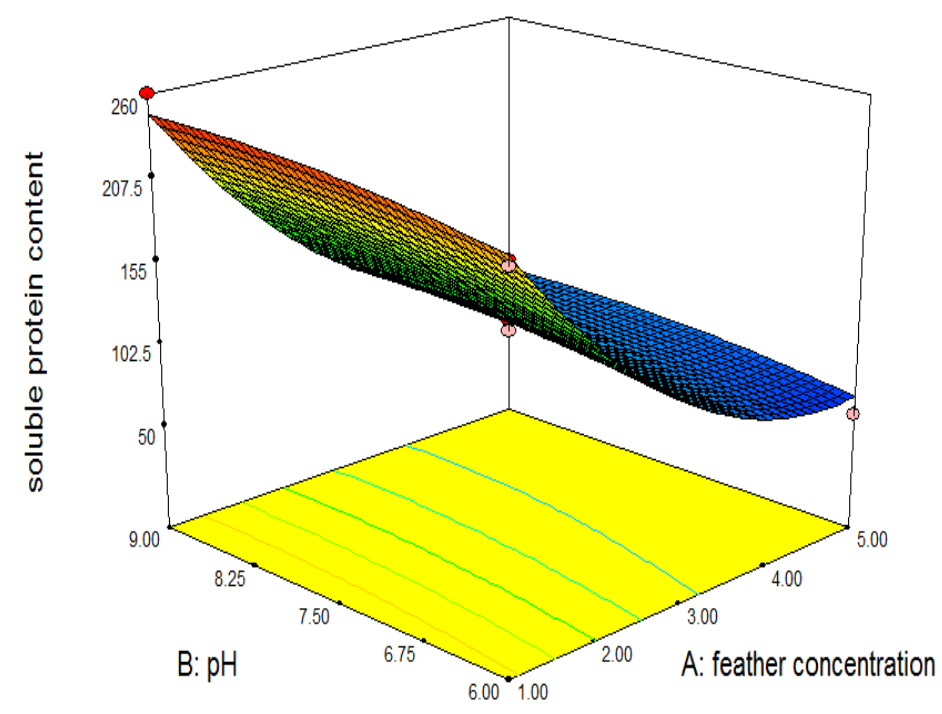

662

663

664

665

666

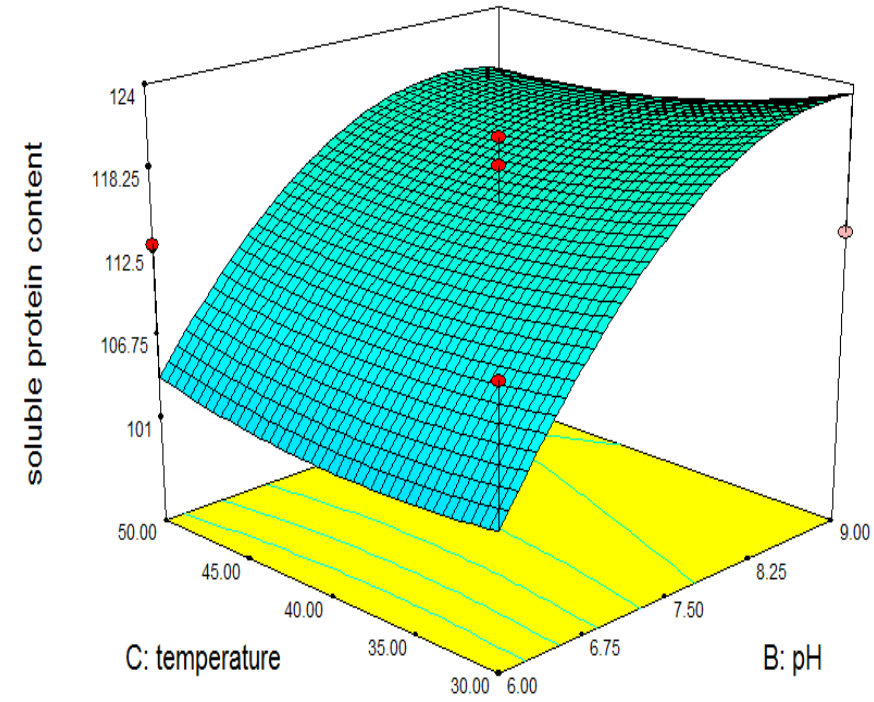

667

668

669

670

671

672

673

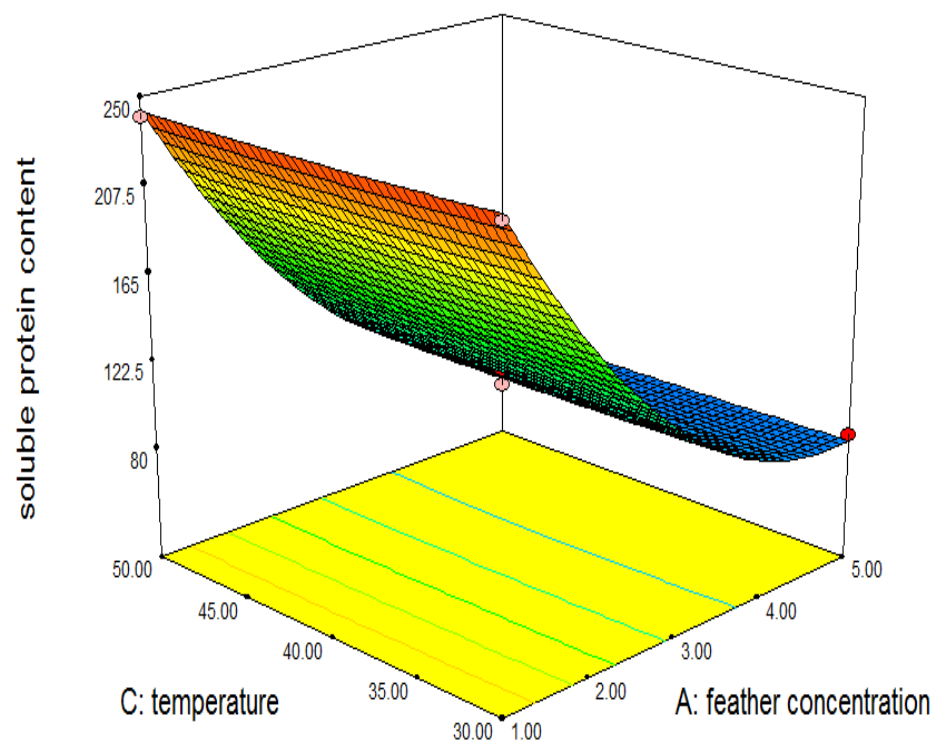


$675 \quad$ Figure 3 (b)

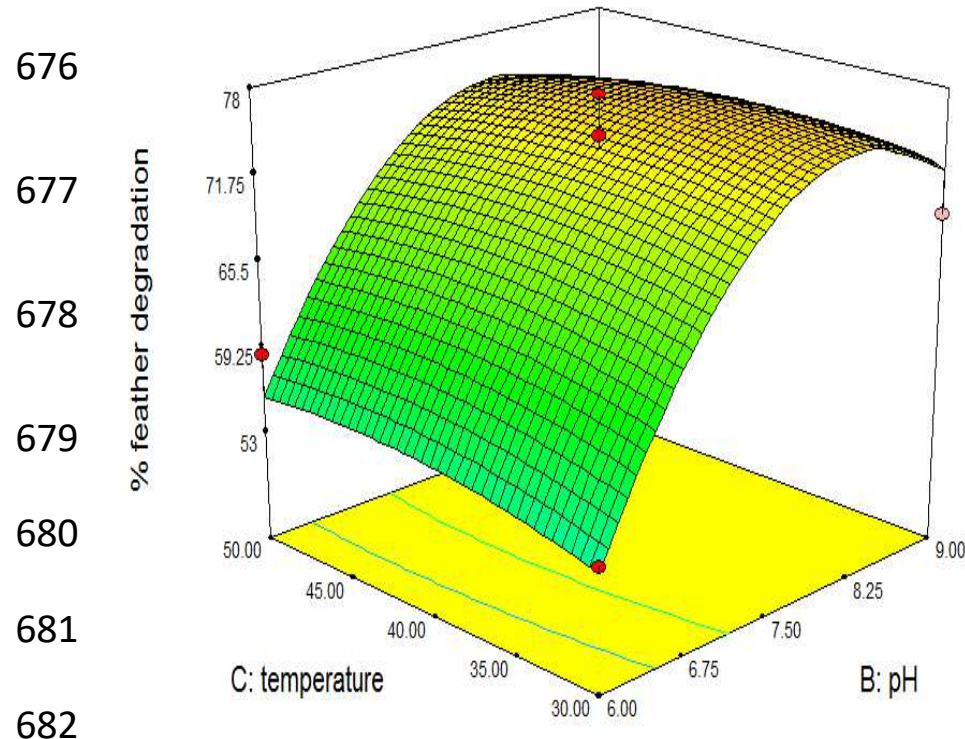

683

684

685

686

687

688

689

690

691

692

693

694

695

696

697
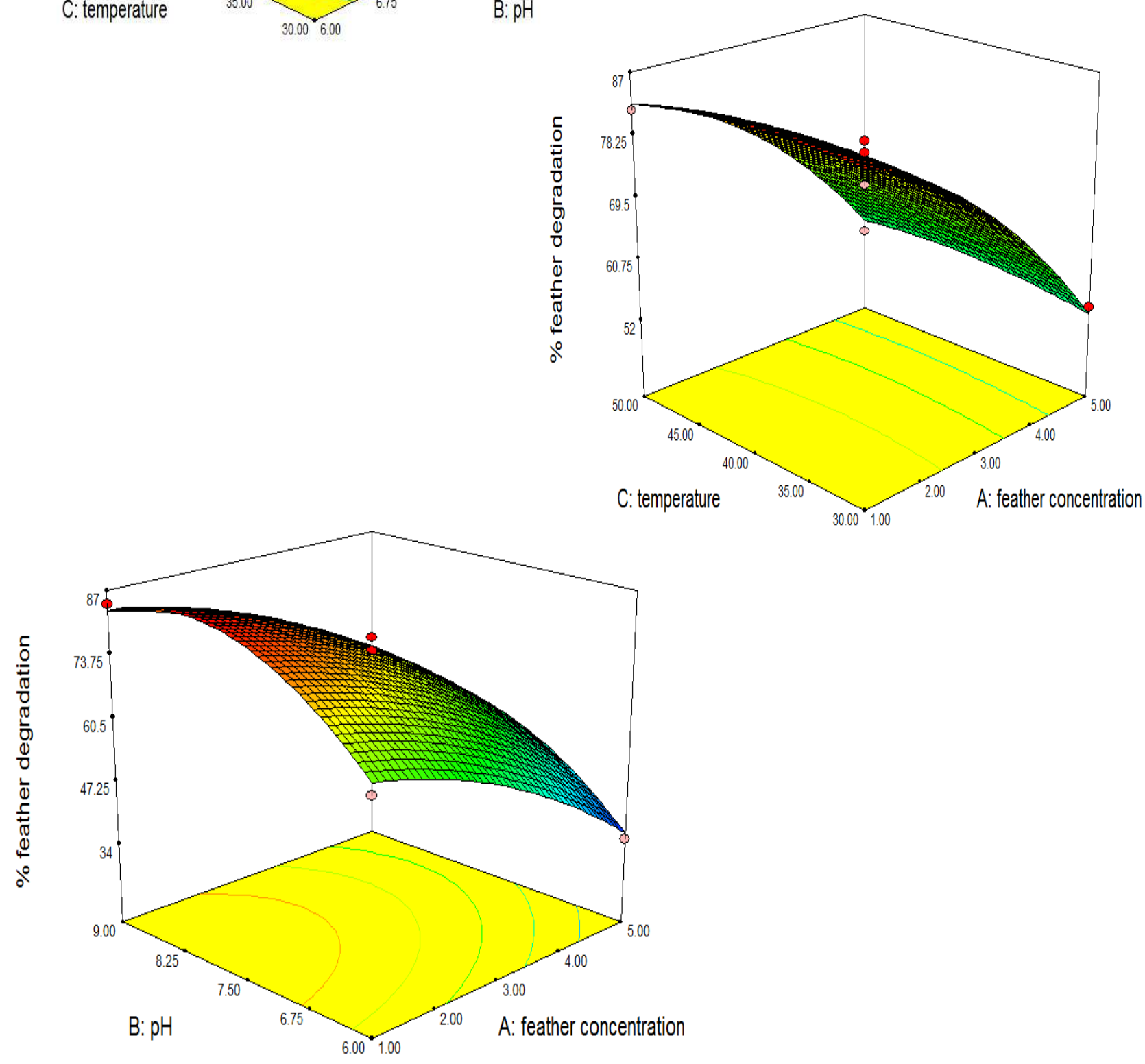

698 
Figure 4

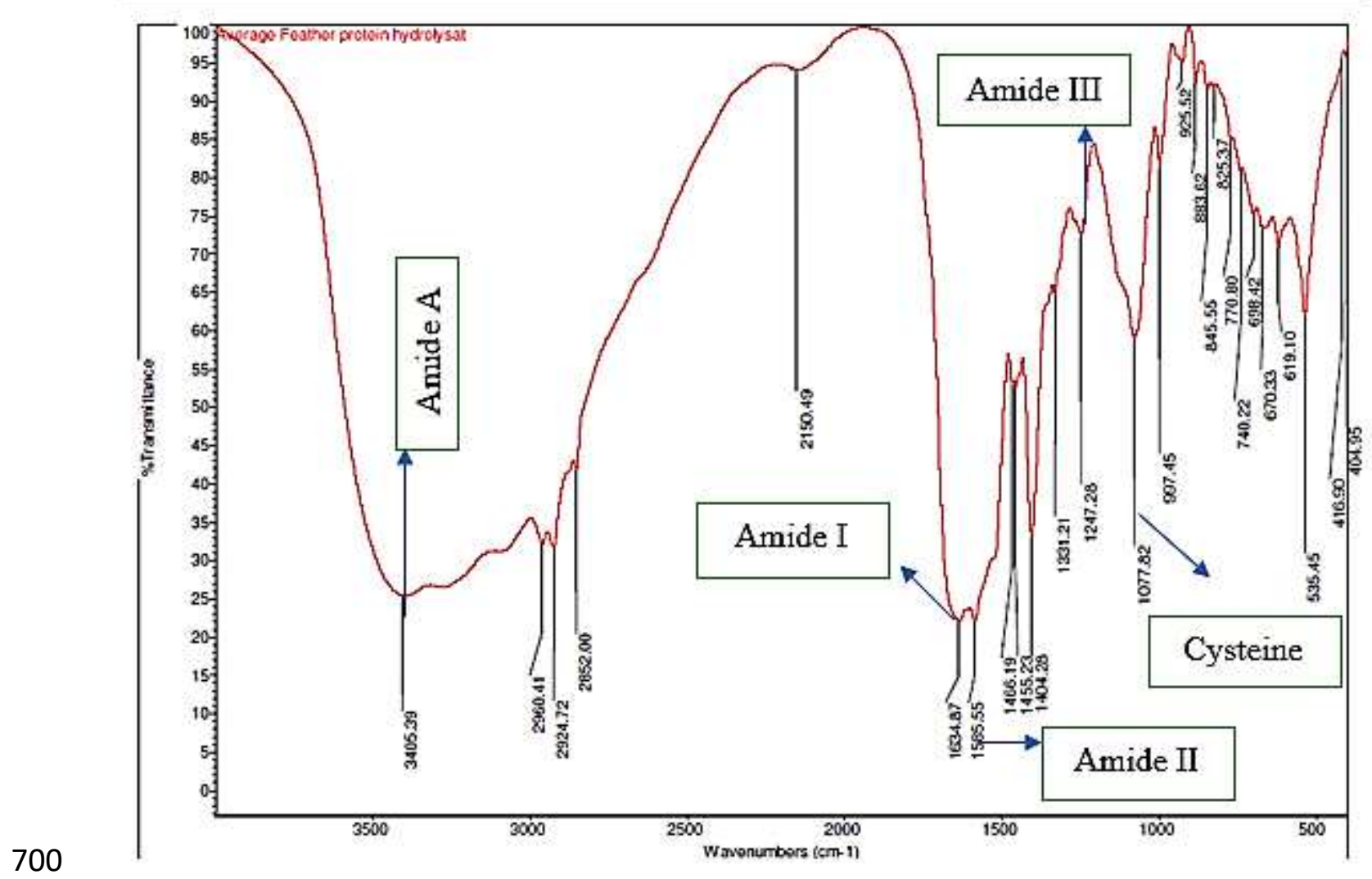

$701 \quad$ Figure 5

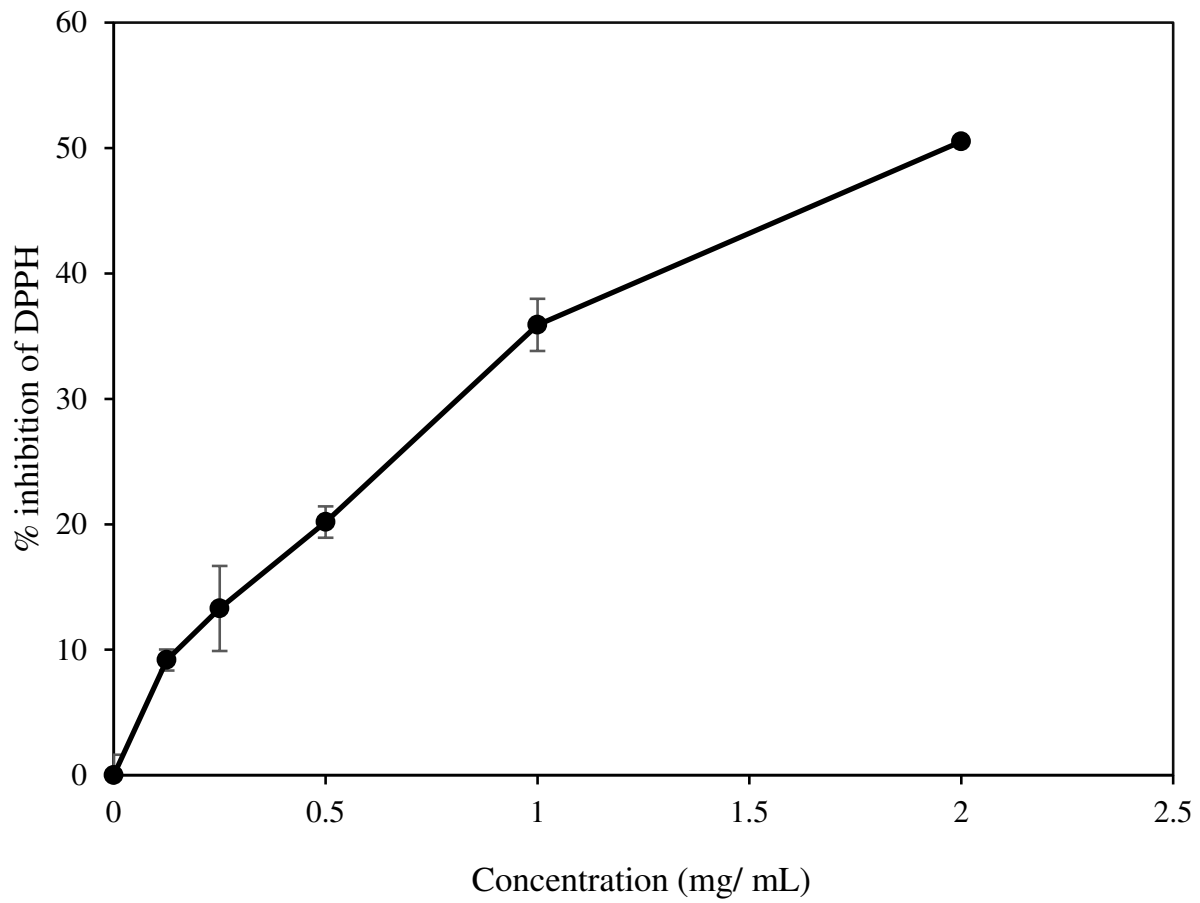


704

705 Table 1. Degree of feather degradation (DFD) and total soluble proteins (TSP) of bacterial 706 isolates from chicken farm bed.

\begin{tabular}{lll}
\hline Bacterial isolates & DFD $(\%)$ & TSP $(\mathrm{mg} / \mathrm{g})$ \\
\hline KB1 & $74.78 \pm 2.94^{\mathrm{a}}$ & $205 \pm 0.03^{\mathrm{a}}$ \\
KB2 & $11.1 \pm 1.23^{\mathrm{f}}$ & $39 \pm 0.06^{\mathrm{e}}$ \\
KB3 & $16.06 \pm 0.66^{\mathrm{def}}$ & $49 \pm 0.04^{\mathrm{cde}}$ \\
KB4 & $57.48 \pm 5.32^{\mathrm{b}}$ & $150.72 \pm 0.04^{\mathrm{b}}$ \\
KB5 & $22.32 \pm 1.88^{\mathrm{d}}$ & $61 \pm 0.03^{\mathrm{c}}$ \\
KB6 & $30.46 \pm 0.98^{\mathrm{c}}$ & $50 \pm 0.06^{\mathrm{edc}}$ \\
KB7 & $20.4 \pm 1.92^{\mathrm{de}}$ & $54 \pm 0.01^{\mathrm{dc}}$ \\
KB8 & $15.43 \pm 2.15^{\mathrm{ef}}$ & $45 \pm 0.03^{\mathrm{ed}}$
\end{tabular}

$707 *$ Values are the means of three replications of a sample \pm SD. Different superscripts alphabet 708 (a-f) used in the same column represent significant difference $(p<0.05)$ 
709 Table 2. Box-Behnken experimental design with experimental and predicted values for

710 soluble protein concentration and degree of feather degradation.

\begin{tabular}{|c|c|c|c|c|c|}
\hline \multirow{2}{*}{$\begin{array}{l}\text { Run } \\
\text { order }\end{array}$} & \multicolumn{3}{|c|}{ Independent variables } & \multicolumn{2}{|c|}{ Response variables } \\
\hline & $\mathrm{X} 1$ & $\mathrm{X} 2$ & $\mathrm{X} 3$ & TSP $(\mathrm{mg} / \mathrm{g})$ & $\% \mathrm{DFD}$ \\
\hline 1 & 1 & 9 & 40 & 260.0 & 86.16 \\
\hline 2 & 3 & 7.5 & 40 & 120.43 & 77.51 \\
\hline 3 & 1 & 6 & 40 & 220.30 & 63.60 \\
\hline 4 & 5 & 9 & 40 & 90.46 & 55.45 \\
\hline 5 & 5 & 6 & 40 & 56.20 & 34.91 \\
\hline 6 & 3 & 9 & 30 & 114.03 & 69.07 \\
\hline 7 & 3 & 9 & 50 & 110.00 & 69.72 \\
\hline 8 & 3 & 7.5 & 40 & 118.50 & 74.60 \\
\hline 9 & 1 & 7.5 & 30 & 242.10 & 84.25 \\
\hline 10 & 5 & 3 & 30 & 86.42 & 53.73 \\
\hline 11 & 3 & 6 & 50 & 113.16 & 58.76 \\
\hline 12 & 1 & 7.5 & 50 & 240.10 & 81.80 \\
\hline 13 & 5 & 7.5 & 50 & 85.96 & 53.0 \\
\hline 14 & 3 & 6 & 30 & 112.16 & 53.0 \\
\hline 15 & 3 & 7.5 & 40 & 111.53 & 71.39 \\
\hline
\end{tabular}

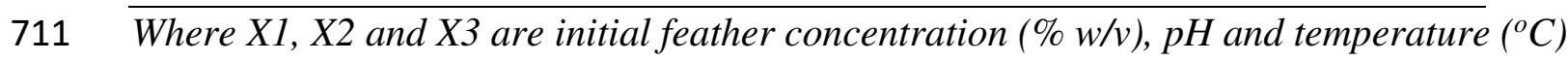
712 respectively. 
713 Table 3. Physico-chemical composition of raw feathers and feather protein hydrolysates.

\begin{tabular}{lll}
\hline Composition $(\%)$ & Raw feathers & Feather protein hydrolysate \\
\hline Protein & $80.73 \pm 1.53$ & $78.45 \pm 0.38$ \\
Fat & $2.30 \pm 0.05$ & $0.034 \pm 0.06$ \\
Moisture & $10.06 \pm 0.66$ & $3.54 \pm 0.04$ \\
Ash & $0.83 \pm 0.07$ & $10.72 \pm 0.04$ \\
In vitro digestibility & $1.75 \pm 0.5$ & $82.36 \pm 0.62$ \\
\hline
\end{tabular}


715 Table 4. Amino acid composition of feather protein hydrolysates.

\begin{tabular}{|c|c|}
\hline Amino Acid & $\begin{array}{l}\text { Composition } \\
(\mathrm{mg} / 100 \mathrm{~g} \text { protein in feather protein hydrolysates }(\mathrm{FPH}))\end{array}$ \\
\hline Alanine & 2.57 \\
\hline Arginine & 2.61 \\
\hline Aspartic acid & 5.51 \\
\hline Cystine & 4.20 \\
\hline Glutamic acid & 7.73 \\
\hline Glycine & 4.93 \\
\hline Histidine $^{*}$ & 0.86 \\
\hline Hydroxylysine & ND \\
\hline Hydrosyproline & ND \\
\hline Isoleucine $^{*}$ & 3.54 \\
\hline Leucine $^{*}$ & 6.25 \\
\hline Lysine* & 3.78 \\
\hline Methionine* & 0.99 \\
\hline Phenylalanine* & 5.13 \\
\hline Proline & 5.84 \\
\hline Serine & 4.50 \\
\hline Threonine $^{*}$ & 2.17 \\
\hline Tryptophan* & 0.81 \\
\hline Tyrosine & 4.25 \\
\hline Valine* & 5.66 \\
\hline
\end{tabular}

716 (*) denotes the essential amino acids

$717 N D=$ Not Detected

718 


\section{Figures}

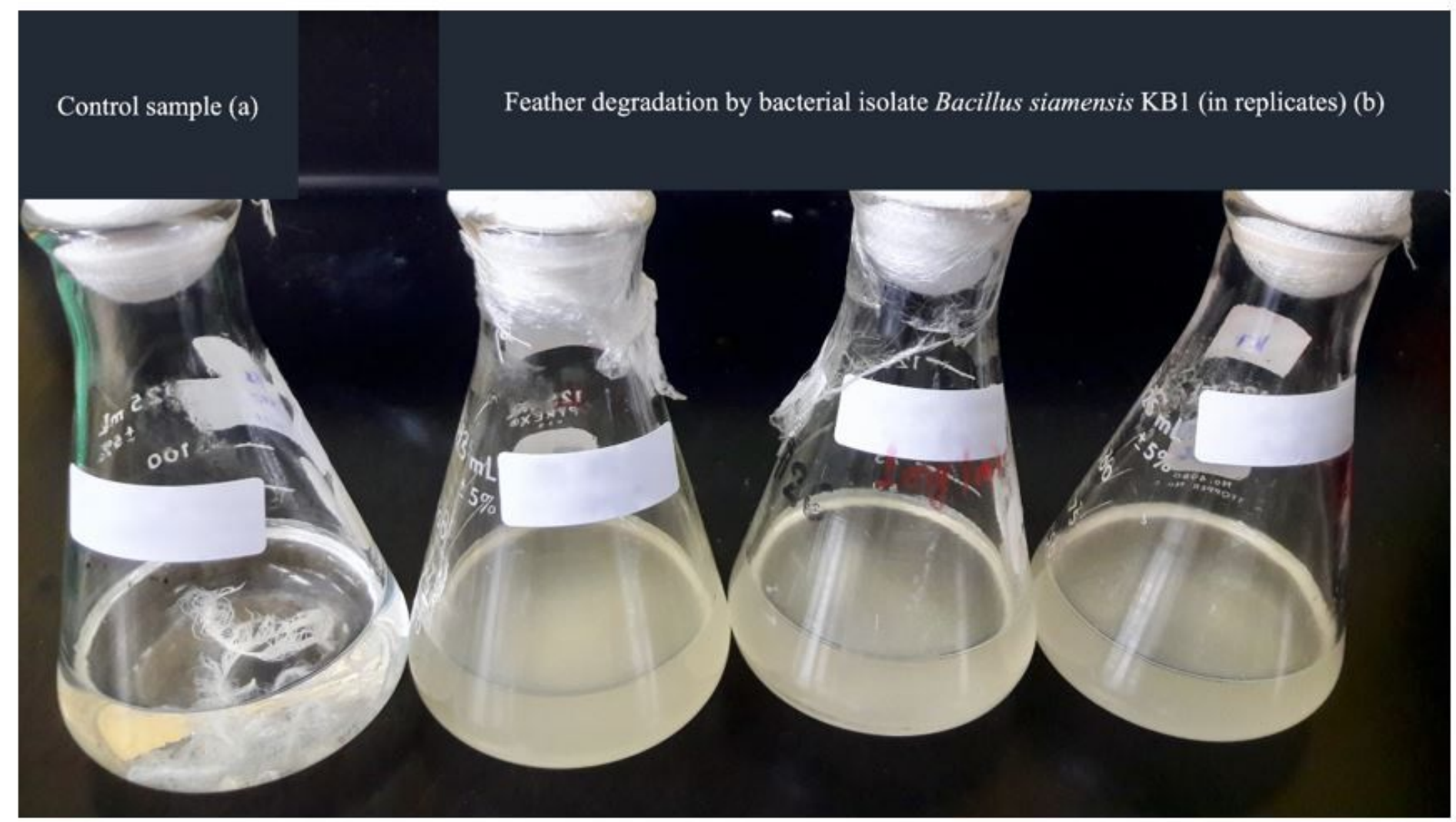

\section{Figure 1}

Chicken feather degradation by bacterial isolate KB1 (a) control (without bacteria) and (b) solubilized feather by bacterial isolate KB1 in a minimal basal media 


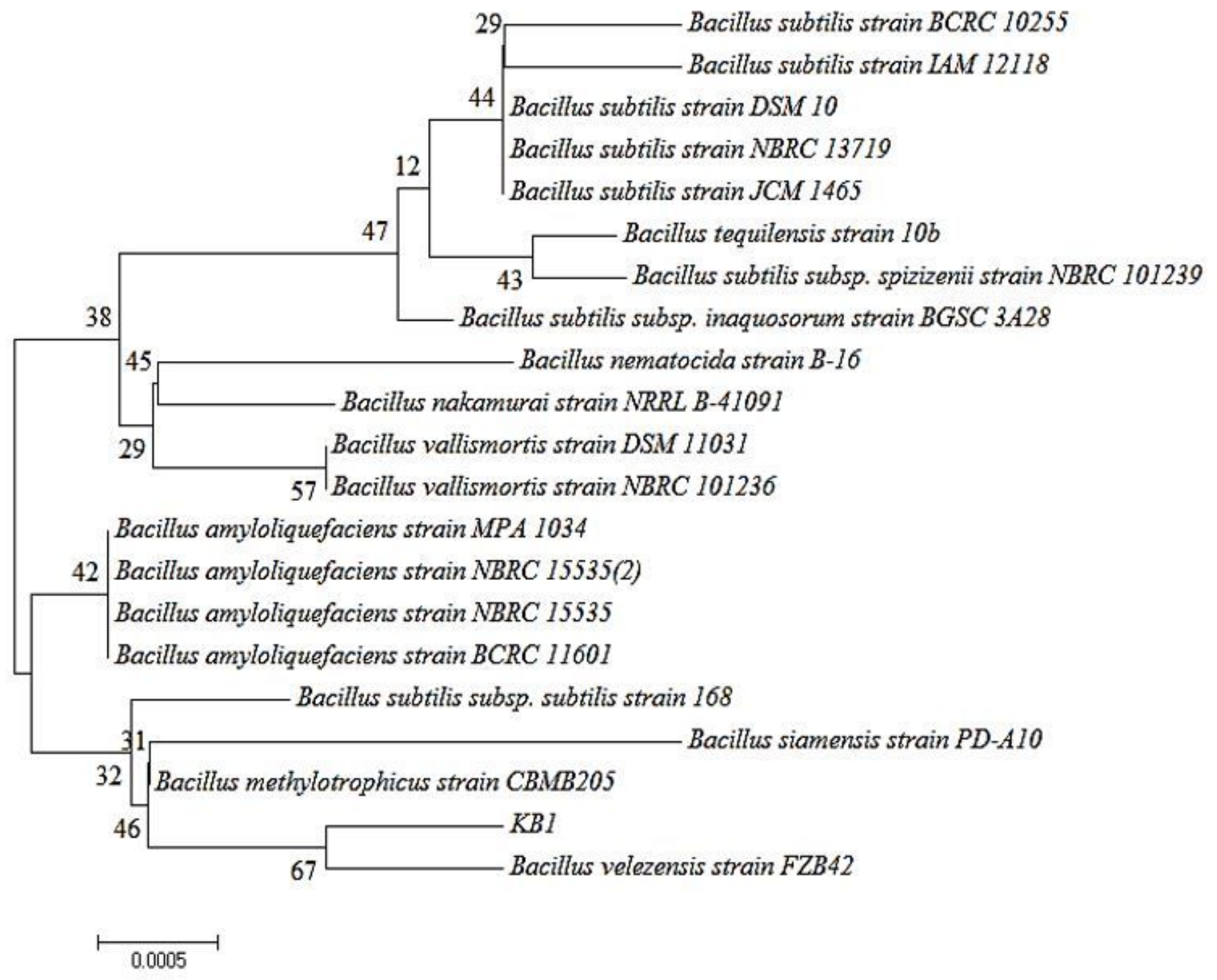

Figure 2

Phylogenetic relationship of the 16S rDNA sequence of keratinolytic bacteria KB1 with 16S rDNA of closest Bacillus species 

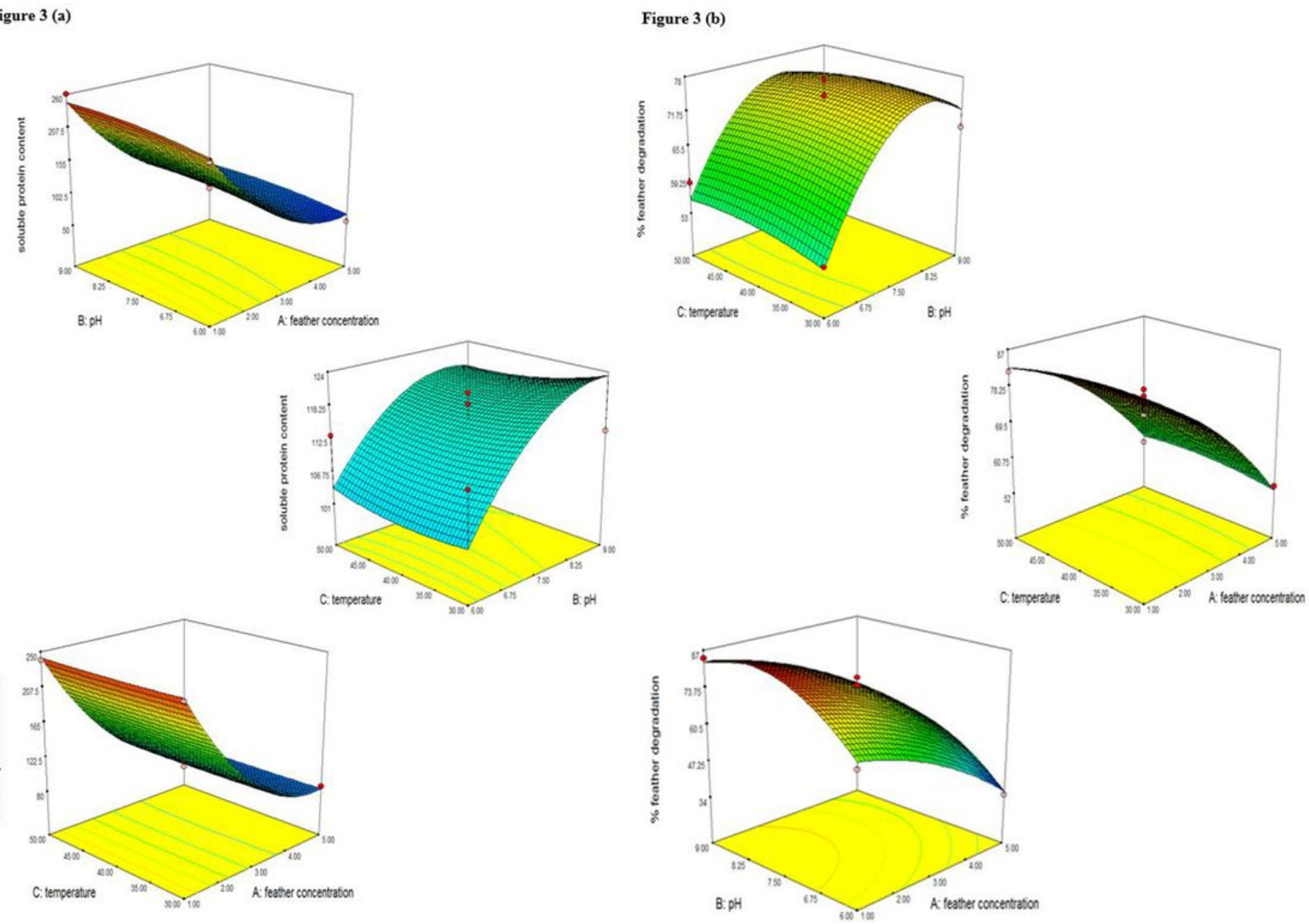

\section{Figure 3}

(a) 3-D response surface plot showing the interactive effect of initial $\mathrm{pH}$, initial feather concentration, and temperature on the production of total soluble protein (b) 3-D response surface plot showing interactive effect of initial $\mathrm{pH}$, initial feather concentration and temperature on the degree of feather degradation 


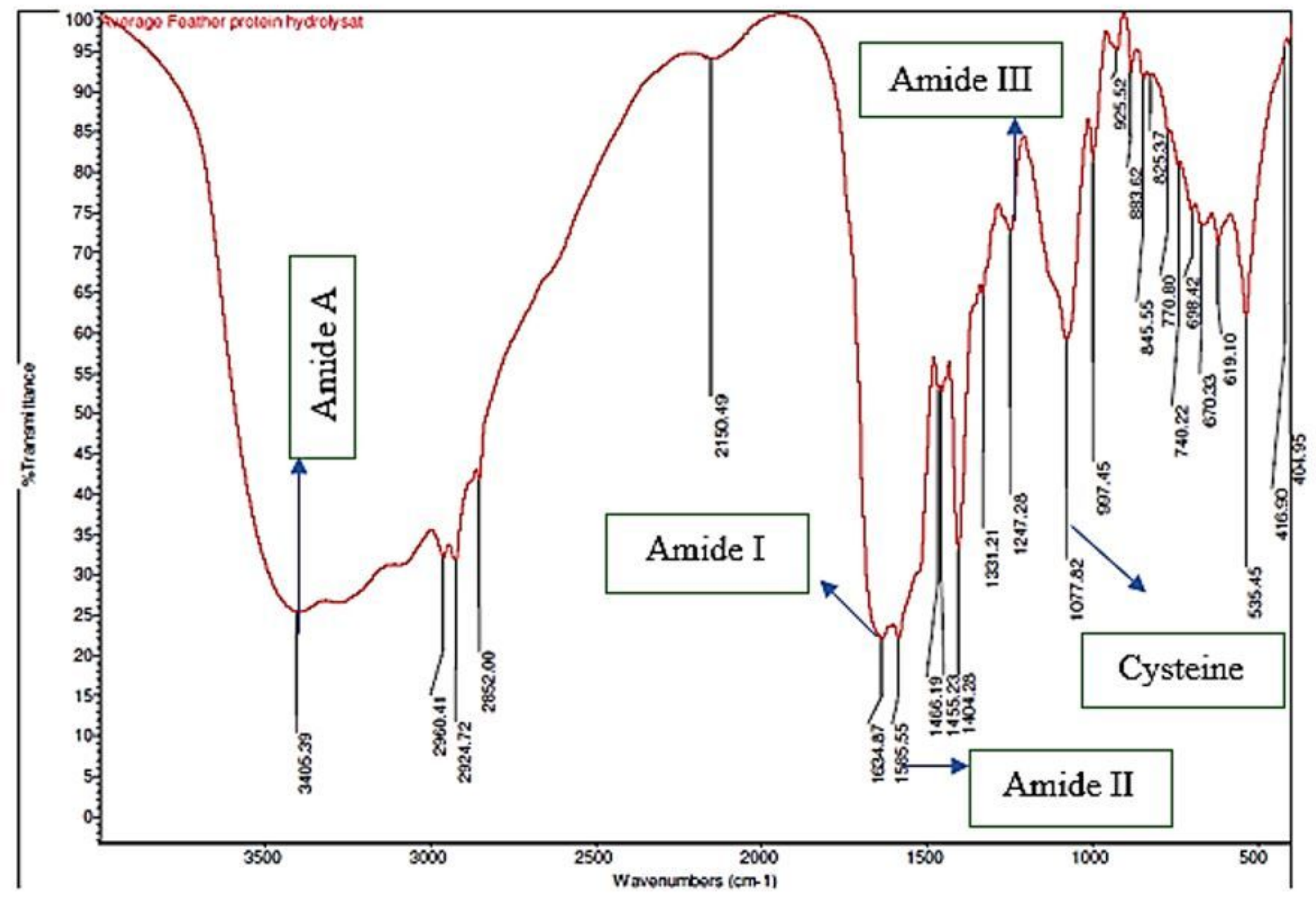

Figure 4

Fourier-transform infrared (FTIR) spectrum of feather protein hydrolysates 


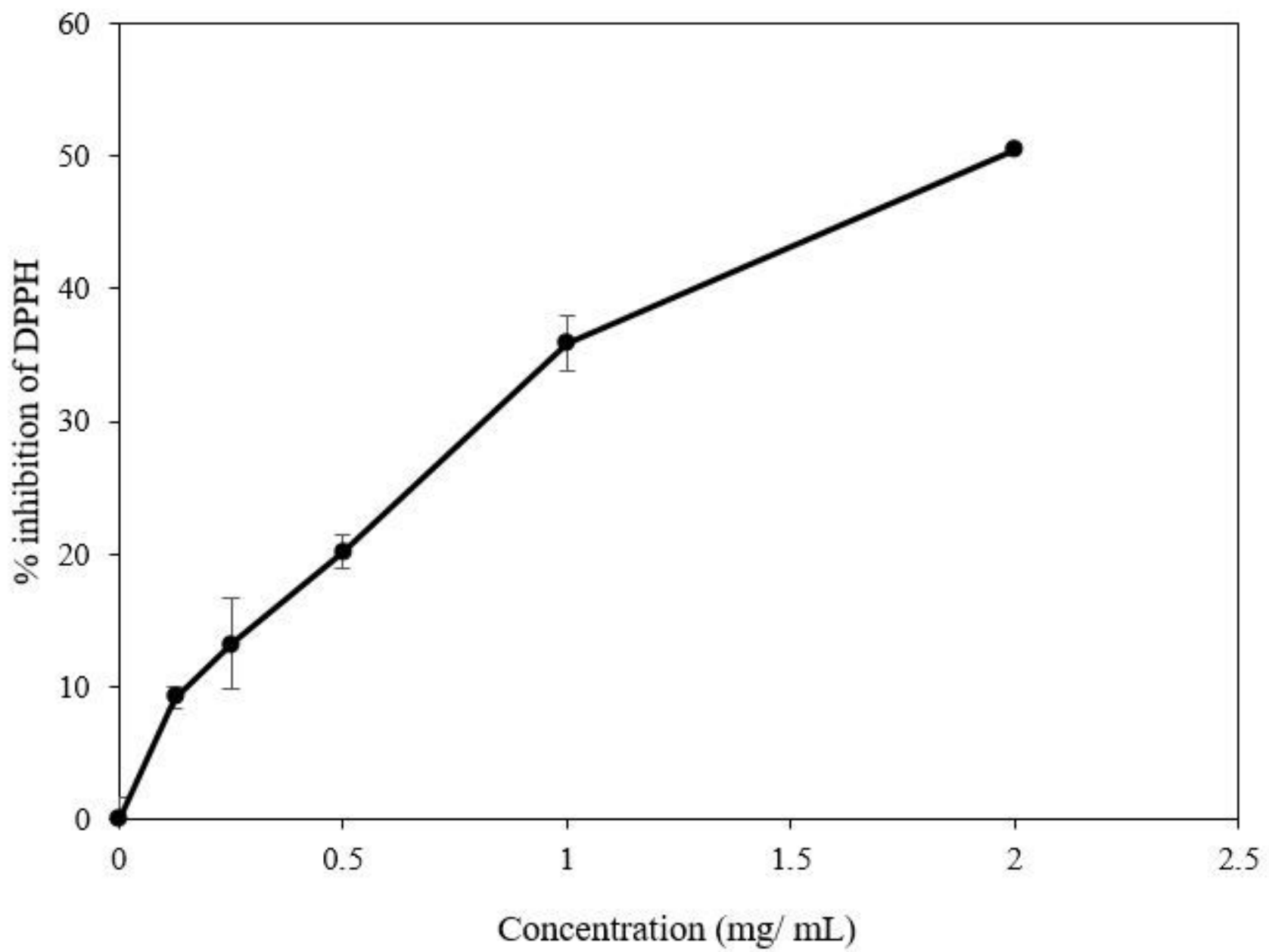

Figure 5

In vitro \% inhibition of DPPH antioxidant activity of feather protein hydrolysates

\section{Supplementary Files}

This is a list of supplementary files associated with this preprint. Click to download.

- GraphicalAbstract.jpg 